\title{
Epigean (pond-dwelling) species of the genus Niphargus Schiödte, 1849 (Crustacea: Amphipoda: Niphargidae) from the coastal plains of the Black and Azov seas of the north- and south-western Caucasus
}

\author{
D.M. Palatov', I.N. Marin ${ }^{2}$
}

A.N. Severtsov Institute of Ecology and Evolution of RAS, Leninsky prospect 33, Moscow 119071, Russia.E-mails:triops@yandex.rul, coralliodecapoda@mail.ru ${ }^{2}$

ABSTRACT: Four epigean species of the genus Niphargus Schiödte, 1849 (Crustacea: Amphipoda: Niphargidae), namely N. hrabei S. Karaman, 1932, N. valachicus Dobreanu et Manolache, 1933, N. magnus Birštein, 1940, N. potamophilus Birštein, 1954, were recorded as pond dwellers on the coastal plains of the Black and Azov seas of the north- and south-western Caucasus. N. potamophilus and N. magnus were re-described based on topotypic material; the first species is distributed in the lower part of the coastal plain of the Sea of Azov between the deltas of the Kuban and Don rivers, while the latter taxon is a complex of several cryptic species that are widely distributed in the Kolkhida coastal lowland plain of the eastern Black Sea (Colchis) from Russia to the north-eastern Turkey. $N$. cubanicus Birštein, 1954 was found to be a junior synonym of $N$. hrabei, which was firstly reported from the Russian Caucasus, in the upper part of the coastal plain of the Sea of Azov from the Kuban River delta. N. valachicus was firstly reported from the Colchis near Poti, Georgia. Neotypes based on topotypic material were selected for N. potamophilus and $N$. magnus, since the original type material was lost. Molecular genetic data for these Caucasian species are presented for the first time.

How to site this article: Palatov D.M., Marin I.N. 2021. Epigean (pond-dwelling) species of the genus Niphargus Schiödte, 1849 (Crustacea: Amphipoda: Niphargidae) from the coastal plains of the Black and Azov seas of the north- and south-western Caucasus // Invert. Zool. Vol.18. No.2. P.105-151. doi: 10.15298/invertzool.18.2.05

KEY WORDS: Crustacea, Amphipoda, Niphargidae, Niphargus, diversity, epigean, Caucasus, Ciscaucasia.

\section{Эпигейные (прудовые) виды рода Niphargus Schiödte, 1849 (Crustacea: Amphipoda: Niphargidae) с прибрежных равнин Черного и Азовского морей северо- и юго-западного Кавказа}

\author{
Д.М. Палатов ${ }^{1}$, И.Н. Марин ${ }^{2}$
}

Институт экологии и эволючии им. А.Н. Севериова РАН, Ленинский проспект 33, Москва, Россия, 119071.E-mails: triops@yandex.rul, coralliodecapoda@mail.ru²

РЕЗЮМЕ: Четыре эпигейных вида рода Niphargus Schiödte, 1849 (Crustacea: Amphipoda: Niphargidae), а именно N. hrabei S. Karaman, 1932, N. valachicus Dobreanu et Manolache, 1933, N. magnus Birštein, 1940 и N. potamophilus Birštein, 1954, были 
отмечены как «обитатели прудов» на прибрежных равнинах Черного и Азовского морей северо- и юго-западного Кавказа. N. potamophilus и N. magnus переописаны на основе топотипического материала; первый вид распространен на в нижней части Приазовской прибрежной равнины между дельтами рек Кубань и Дон; второй, очевидно, в реальности представляющий собой комплекс из нескольких криптических видов, обитающих в Колхидской прибрежной низменной равнине восточного Причерноморья (Colchis) от черноморского побережья России до северо-восточной Турции. N. cubanicus Birštein, 1954 рассматривается как младший синоним N. hrabei, который таким образом впервые сообщается с русского Кавказа, из дельты реки Кубань нижней части Приазовской прибрежной равнины. N. valachicus впервые обнаружен в водоемах Колхидской низменности Черного моря близ Поти, Грузия. На основе топотипического материала для $N$. potamophilus и $N$. magnus обозначены неотипы, так как оригинальный типовой материал в настоящее время утрачен. Впервые для этих кавказских видов представлены молекулярно-генетические данные.

Как цитировать эту статью: Palatov D.M., Marin I.N. 2021. Epigean (pond-dwelling) species of the genus Niphargus Schiödte, 1849 (Crustacea: Amphipoda: Niphargidae) from the coastal plains of the Black and Azov seas of the north- and south-western Caucasus // Invert. Zool. Vol.18. No.2. P.105-151. doi: 10.15298/invertzool.18.2.05

КЛЮЧЕВЫЕ СЛОВА: Crustacea, Amphipoda, Niphargidae, Niphargus, разнообразие, эпигейные, Кавказ, Предкавказье.

\section{Introduction}

The genus Niphargus Schiödte, 1849 (Crustacea: Amphipoda: Niphargidae) currently includes more than 400 species found in a wide range of subterranean and epigean aquatic habitats in the south-western part of the Western Palearctic, from small pores in the epikarst and deep cave lakes to epigean springs, wells and hyporean zone of rivers (Fišer et al., 2006, 2014; Väinölä et al., 2008; Fišer, 2012; Esmaeili-Rineh et al., 2015; Horton et al., 2017). The diversity of the genus is relatively well studied in the Balkan Peninsula and Western Europe, while other areas of its distribution remain beyond the close interest of specialists. At the same time, the Caucasus follows the Balkan Peninsula in the karst area, variety of landscapes and climatic conditions, being a hotspot of hidden biodiversity, characterized by a unique and very rich fauna, and a putative zone of species endemism, formed by a stable climate, local disjunction of ecological niches and microhabitats (Myers et al., 2000; Krever et al., 2001). More than 40 species of the genus Niphargus have been described in the Caucasus mainly in the early or mid-20th century, and almost all Caucasian species are known as strict endemics of the region (Karaman, 2012; Takhteev et al., 2015; Turbanov et al., 2016; Marin, 2019, 2020; Marin, Palatov, 2019a, b). Recent molecular genetic studies postulate that most Niphargus species have a limited distribution, being mostly narrow endemics (Fišer et al., 2008; Eme et al., 2017; Delić et al., 2017), while widespread taxa represent complexes of cryptic species, even for epigean species (Lefébure et al., 2006, 2007; Delić et al., 2017). These conclusions are also confirmed for the stygobiotic Caucasian species (Marin, 2019, 2020; Marin, Palatov, 2019a, b, 2021; Marin et al., 2021).

Although the underground (stygobiotic) lifestyle seems to be an ancestral condition for the genus Niphargus (McInerney et al., 2014; Esmaeili-Rineh et al., 2015; Delić et al., 2016), not all species of the genus are characterized by this lifestyle, but also live in surface waters. Two epigean species, namely $N$. hrabei Karaman, 1932 and $N$. valachicus Dobreanu et Manolache, 1933, are widely distributed in the European Danube river basin, where they inhabit densely vegetated areas with a muddy 
substrate of lowland springs, streams, channels, ponds and rivers with slow water current, lakes and temporary water bodies, and exhibit very wide geographical ranges for the genus $(>1300$ $\mathrm{km}$ across)(Copilaş-Ciocianu et al., 2014, 2017, 2018). In the Caucasus and the plains of the Ciscaucasia, strictly epigean species with a similar ecology are $N$. potamophilus Birštein, 1954, originally described from the ponds of the experimental fish farm in the Don River delta, the floodplain reservoir in the vicinity of Rostovon-Don (Rostov region) and Atkhyr fish farms in the Kuban River delta (Krasnodar Krai), and N. cubanicus Birštein, 1954, originally described from a well-warmed pond at the fish hatchery near Goryachiy Klyuch (Krasnodar Krai) (Birštein, 1954). The original descriptions of both species were given in the 1950s, and are rather incomplete according to modern taxonomic standards, while the absence of any molecular genetic data concerning these taxa also does not allow us to determine the exact phylogenetic position of these species. In addition, the listed species share several morphological features such as stout body (except $N$. magnus), quadrate palm (chela) of gnathopods I-II, acutely produced posteroventral corners of epimeral plates I-III and, especially, the presence of a spoon-shaped projection at the base of rami of uropod I in males, which previously was the reason to assign them to the obsolete subgenus Phaenogammarus Dudich, 1941 (Straškraba, 1972; Sket, 1981), and which indicates their taxonomic proximity. However, the Caucasian epigean species have never been compared using integrative taxonomy with the species from the Balkans and other parts of Europe.

The aim of our study and this article was an integrative revision of the epigean (pond-dwelling) species of the genus Niphargus from the coastal plains of the Black Sea and the Sea of Azov of the north- and south-western Caucasus.

\section{Material and methods}

Amphipods were collected by hand nets in small ponds and slow-flowing rivers, lakes and temporary reservoirs in the coastal plains of the
Black Sea and the Sea of Azov seas of the northand south-western Caucasus (Russian Federation, Abkhazia and Georgia) (see Fig. 1). Live specimens of Niphargus were taken to the laboratory, relaxed with a clove oil, and photographed using a Canon G16 digital camera. All collected specimens were stored in $90 \%$ solution of ethanol for further DNA analysis. The body length (bl., mm), the dorsal length from the distal margin of head to the posterior margin of telson, without the length of uropod 3 and antennas, is used as a standard measurement. Photographs of body parts were made with a digital camera attached to light microscope Olympus ZX10 and Olympus CX21. Scanning electron microscopy (SEM) photos were made in the Orlov Paleontological Museum of the Paleontological Institute of Russian Academy of Sciences (Moscow, Russia) using Vega3 Tescan microscope. The studied material was deposited at the collection of Zoological Museum of Moscow State University, Moscow, Russia (ZMMU), and the Laboratory of Ecology and Evolution of Marine Invertebrates of A.N. Severtsov Institute of Ecology and Evolution of Russian Academy of Sciences, Moscow, Russia (LEMMI).

Cytochrome c oxidase subunit I (COI) mtDNA was used as one of the most informative gene markers for genetic studies at population and species level to confirm the phylogenetic relationships of the studied species (Avise, 1993; Hebert et al., 2003a, b). Total genomic DNA was extracted from muscle tissue using the innuPREP DNA Micro Kit (AnalitikJena, Germany). The COI mtDNA gene marker was amplified with the help of the universal primers LCO1490 (5'-GGTCAACAAATCATAAAGATATTGG-3') and HC02198 (5'-TAAACTTCAGGGTGACCAAAAAATCA-3')(Folmer et al., 1994). PCRs were performed using the amplificator T100 (Bio-Rad, USA) under the following conditions: initial denaturation at $96^{\circ} \mathrm{C}$ for $1.5 \mathrm{~min}$ followed by 42 cycles of $95^{\circ} \mathrm{C}$ for 2 min, $49^{\circ} \mathrm{C}$ for $35 \mathrm{~seconds}$, and $72^{\circ} \mathrm{C}$ for $1.5 \mathrm{~min}$, followed by chain extension at $72^{\circ} \mathrm{C}$ for $7 \mathrm{~min}$. The volume of $10 \mathrm{uL}$ of reaction mixture contained $1 \mathrm{uL}$ of total DNA, $2 \mathrm{uL}$ of $5 \mathrm{xPCR}$ mix 

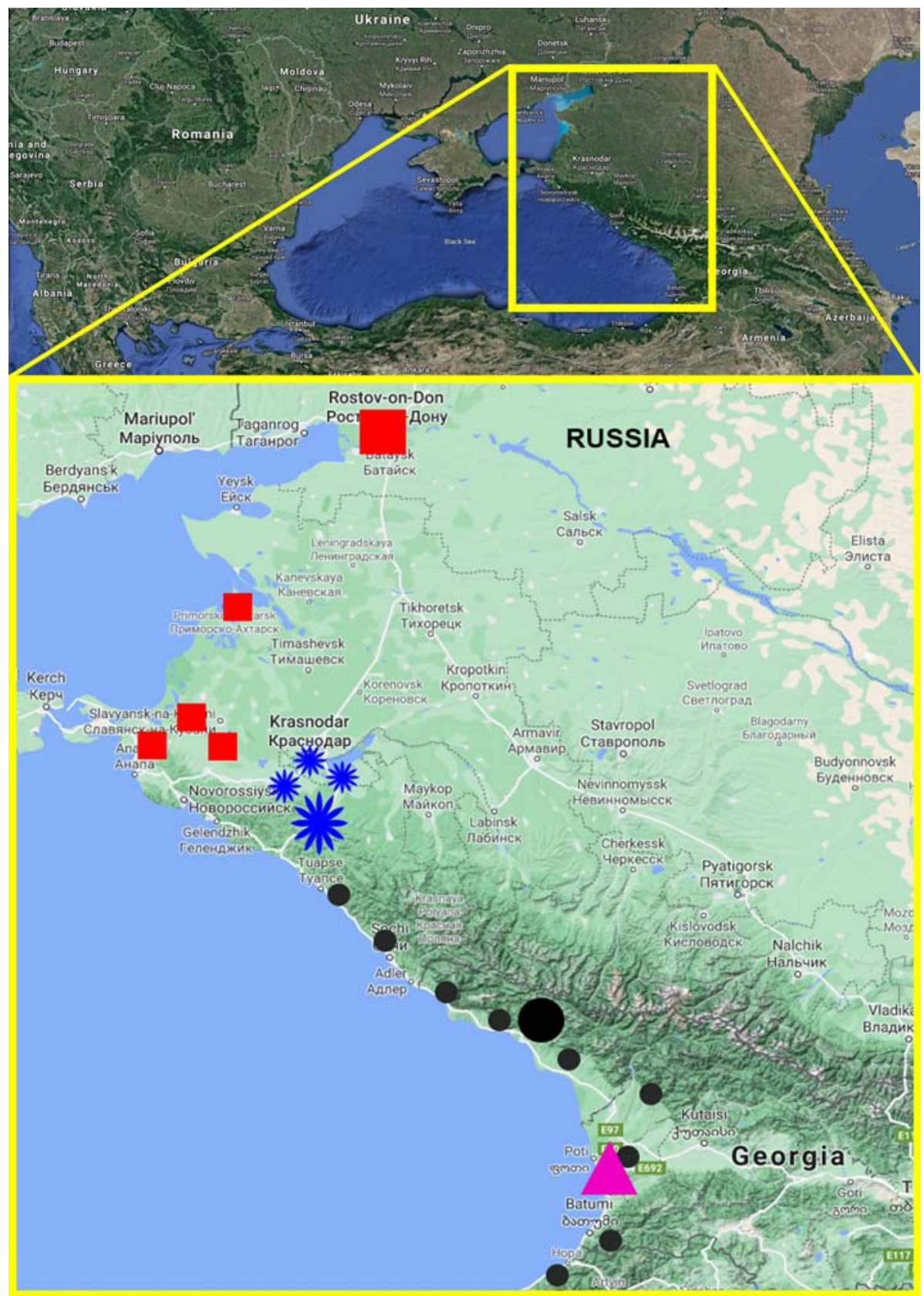

Fig. 1. The map of distribution (records) of Niphargus potamophilus Birštein, 1954 (red squares), N. hrabei S. Karaman, 1932 (blue stars), N. valachicus Dobreanu et Manolache, 1933 (pink triangle) and N. magnus Birštein, 1940 (species complex) (black circles) on the coastal plains of the north-western (the Sea of Azov) and south-western (the Black Sea) Caucasus. Larger figures represent type localities.

Рис. 1. Карта распространения (находок) Niphargus potamophilus Birštein, 1954 (красные квадраты), N. hrabei Karaman, 1932 (синие звездочки), N. valachicus Dobreanu et Manolache, 1933 (розовый треугольник) и N. magnus Birštein, 1940 (комплекс видов) (черные кружки) на прибрежных равнинах северо-западного (Азовское море) и юго-западного (Черное море) Кавказа. Более крупные фигуры обозначают типовые местонахождения. 
(Dialat, Russia) and 1uL of each primer. The amplification products were separated by using gel electrophoresis of nucleic acids on a $1.5 \%$ agarose gel in $1 \mathrm{xTBE}$, and then stained and visualized with $0.003 \%$ EtBr using imaging UV software. DNA nucleotide sequences were determined using Genetic Analyzer ABI 3500 (Applied Biosystems, USA) and BigDye 3.1 (Applied Biosystems, USA) with direct and reverse primers. Dataset of aligned sequences of COI mtDNA gene markers, about 658 base pairs in length used in the study were taken from GenBank (NCBI) and original data.

Consensus of complementary sequences was obtained with MEGA 7.0. The best evolutionary substitution model was determined using MEGA 7.0 and jModeltest2.1.141. A phylogenetic analysis was conducted using PhyML 3.0 (http://www.atgc-montpellier.fr/phyml/)(Guindon et al., 2010) and RAxML (https://raxmlng.vital-it.ch) (Kozlov et al., 2019) with several models based on AIC (Akaike Information Criterion). The tree with the higher bootstrap probability were used for graphic display of relationships within the family. Bootstrap support is presented for ML analysis. Pairwise genetic divergences ( $p$-distances) was calculated based on COI sequences using MEGA 7.0 with the Kimura 2-Parameter (K2P) model of evolution (Kimura, 1980). For the comparison were used all available sequences (COI mtDNA) of $N$. hrabei and N. valachicus deposited in GenBank (NCBI).

Only primary synonyms are presented in the species descriptions.

\section{Results}

\section{Taxonomic part}

Order Amphipoda Latreille, 1816

Family Niphargidae Bousfield, 1977

Genus Niphargus Schiödte, 1849

\section{Niphargus hrabei S. Karaman, 1932}

Figs 2A; 3-7; 13A-D.

Niphargus tatrensis hrabei S. Karaman, 1932: 194197, fig. 7, a-e, fig. 8, a-c.

Niphargus hrabei S. Karaman, 1932
Niphargus thermalis Dudich, 1941: 165-176, figs 1-3. fig. 2 .

Niphargus cubanicus Birštein, 1954: 1028-1030,

MATERIAL EXAMINED. $\sigma^{7}$ (bl. $\left.5 \mathrm{~mm}\right)$, ㅇ (bl. 8 mm), ZMMU Mb-1178, Russia, Krasnodar Krai, Goryachy Klyuch Urban Okrug, an oxbow lake in valley of the Psekups river on outskirts of the Goryachy Klyuch, $44^{\circ} 39.589^{\prime} \mathrm{N}$, $39^{\circ} 09.444^{\prime} \mathrm{E}$, about $54 \mathrm{~m}$ above sea level, hand net sampling, 11 May 2019, coll. I. Marin \& D. Palatov; 2200 , Russia, Krasnodar Krai, same locality, collectors and data; $3 \circ \circ$, Russia, Republic of Adygea, Takhtamukaysky District, rice checks near the Prikubansky farm, $44^{\circ}$ $56.953^{\prime} \mathrm{N}, 39^{\circ} 00.696^{\prime} \mathrm{E}$, about $17 \mathrm{~m}$ above sea level, hand net sampling, 11 May 2019, coll. I. Marin \& D. Palatov; $50^{7} \sigma^{7}, 24$ 우, Russia, Republic of Adygea, Takhtamukaysky District, a small pond near Prikubansky farm, $44^{\circ} 56.947^{\prime} \mathrm{N}$, $39^{\circ} 01.975^{\prime} \mathrm{E}$, about $20 \mathrm{~m}$ above sea level, hand net sampling, 11 May 2019, coll. I. Marin \& D. Palatov; 3 +o, Russia, Republic of Adygea, Adygeysk Urban Okrug, fire pond near a gas station near the Psekups settlement, $44^{\circ} 50$. $316^{\prime} \mathrm{N}, 39^{\circ} 12.783^{\prime} \mathrm{E}$, about $30 \mathrm{~m}$ above sea level, hand net sampling, 11 May 2019, coll. I. Marin \& D. Palatov.

DESCRIPTION.

BODY: violet or blue-whitish, moderately slender.

HEAD (Fig. 13B): without rostrum, with yellow pigmented spots close to anterior lobe and with subrounded lateral cephalic lobes and excavated anteroventral sinus.

PEREON: pereonites I-VII without setae, smooth.

PLEOSOMA: pleonites I-III with several short marginal setae on each posterodorsal margin.

EPIMERAL PLATES (Fig. 6A-C): posteroventral corners of epimeral plates I-III with significantly produced acute posteroventral corners. Epimeral plate I: posterior and ventral margin almost straight; without spines along ventral margin; with 2 setae along posterior margin; posteroventral angle tapered into a spike. Epimeral plate II: posterior margin straight, ventral margin distinctly convex; with 2 spiniform setae along ventral margin; 4 setae along 

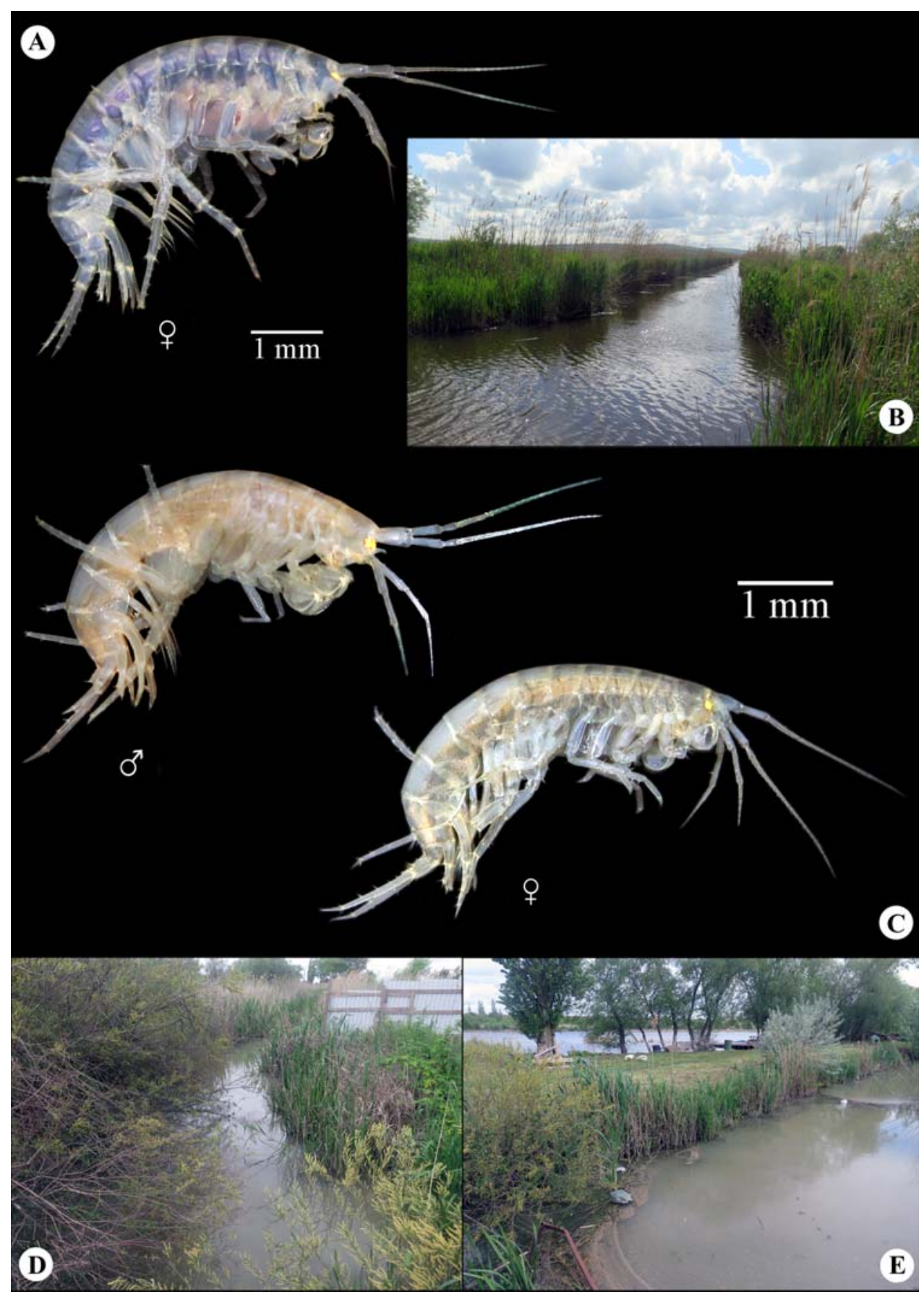

Fig. 2. Alive coloration (A, C) and the habitats (B, D, E) of Niphargus hrabei S. Karaman, 1932 (A, B) and N. potamophilus Birštein, 1954 (C-E) on the coastal plain of the Sea of Azov (north-western Caucasus). Рис. 2. Прижизненная окраска (А, С) и местообитания (B, D, E) Niphargus hrabei S. Karaman, 1932 (A, B) и N. potamophilus Birštein, 1954 (C-E) на прибрежной равнине Азовского моря (северозападный Кавказ). 


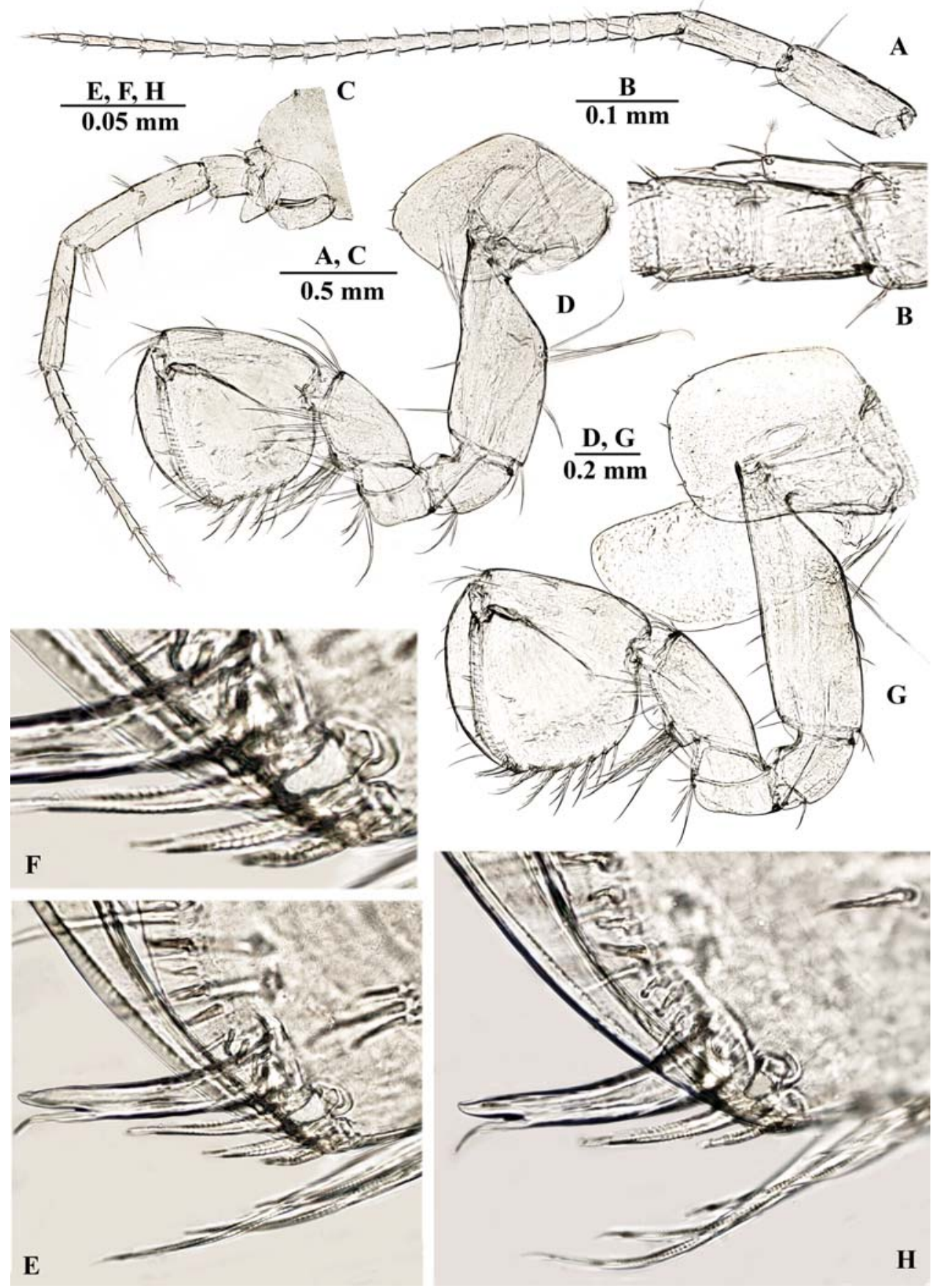

Fig. 3. Niphargus hrabei S. Karaman, 1932, Ơ: A — antenna I; B - accessory flagellum of antenna I; C antenna II; D - gnathopod I; E, F - distoventral corner of chela of GnI; G - gnathopod II; H — distoventral corner of chela of GnII.

Pис. 3. Niphargus hrabei S. Karaman, 1932, Оج: A — антенна I; В - вспомогательный жгутик антенны I; C — антенна II; D — гнатопод I; E, F — дистовентральный угол клешни GnI; G — гнатопод II; H дистовентральный угол клешни GnII. 


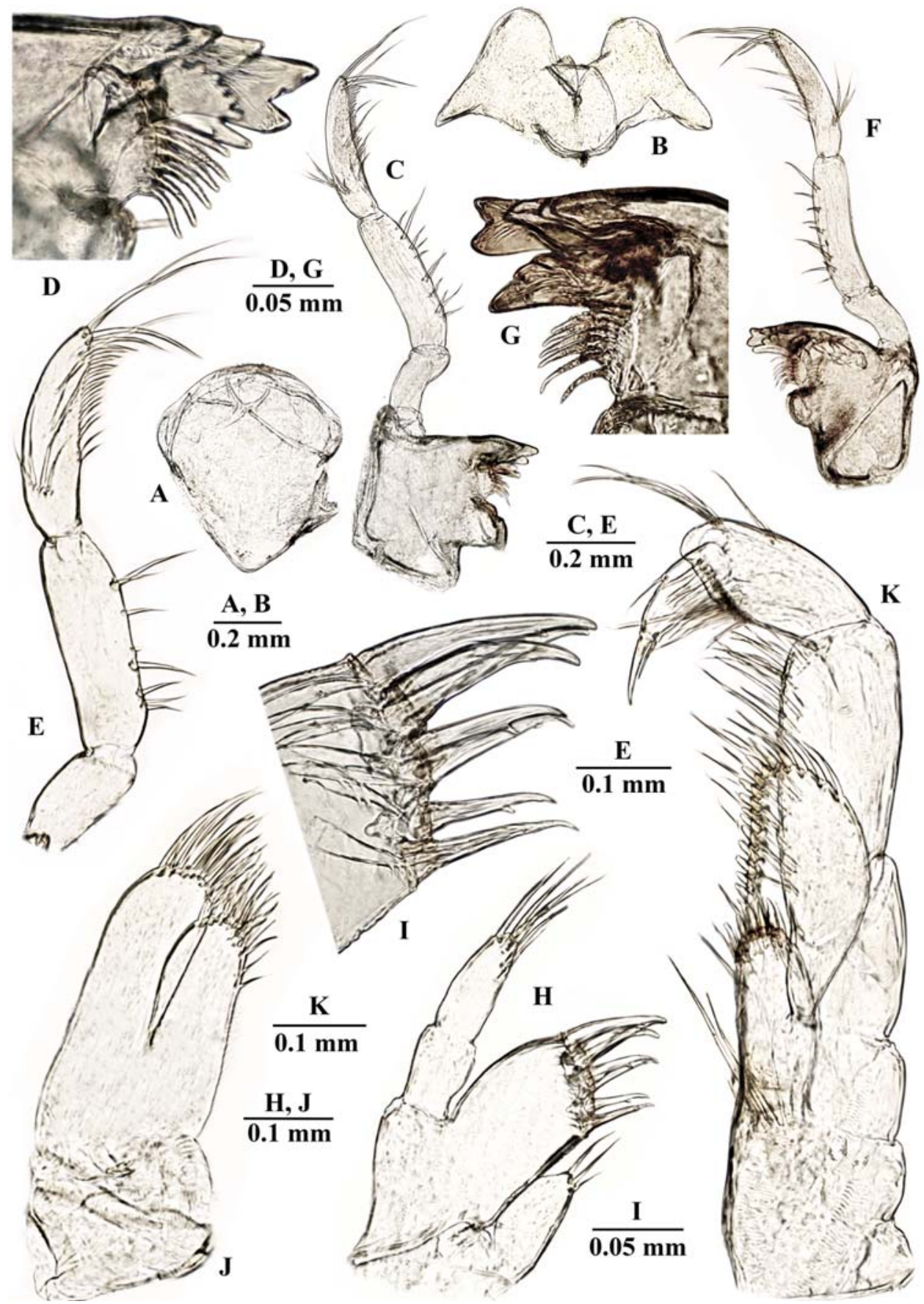

Fig. 4. Niphargus hrabei S. Karaman, 1932, O: A - upper lip; B — lower lip; C, F - mandible; D, G incisor process and pars incisiva of mandible; $\mathrm{H}$ - maxilla I; I - same, distal margin of outer lobe; J maxilla II; $\mathrm{K}$ - maxilliped.

Pис. 4. Niphargus hrabei S. Karaman, 1932, О: А — верхняя губа; В — нижняя губа; C, F — мандбула; $\mathrm{D}, \mathrm{G}$ - резцовый отросток и pars incisiva мандибулы; H — максилла I; I — то же, дистальный край наружной доли; J — максилла II; K — максиллипед. 


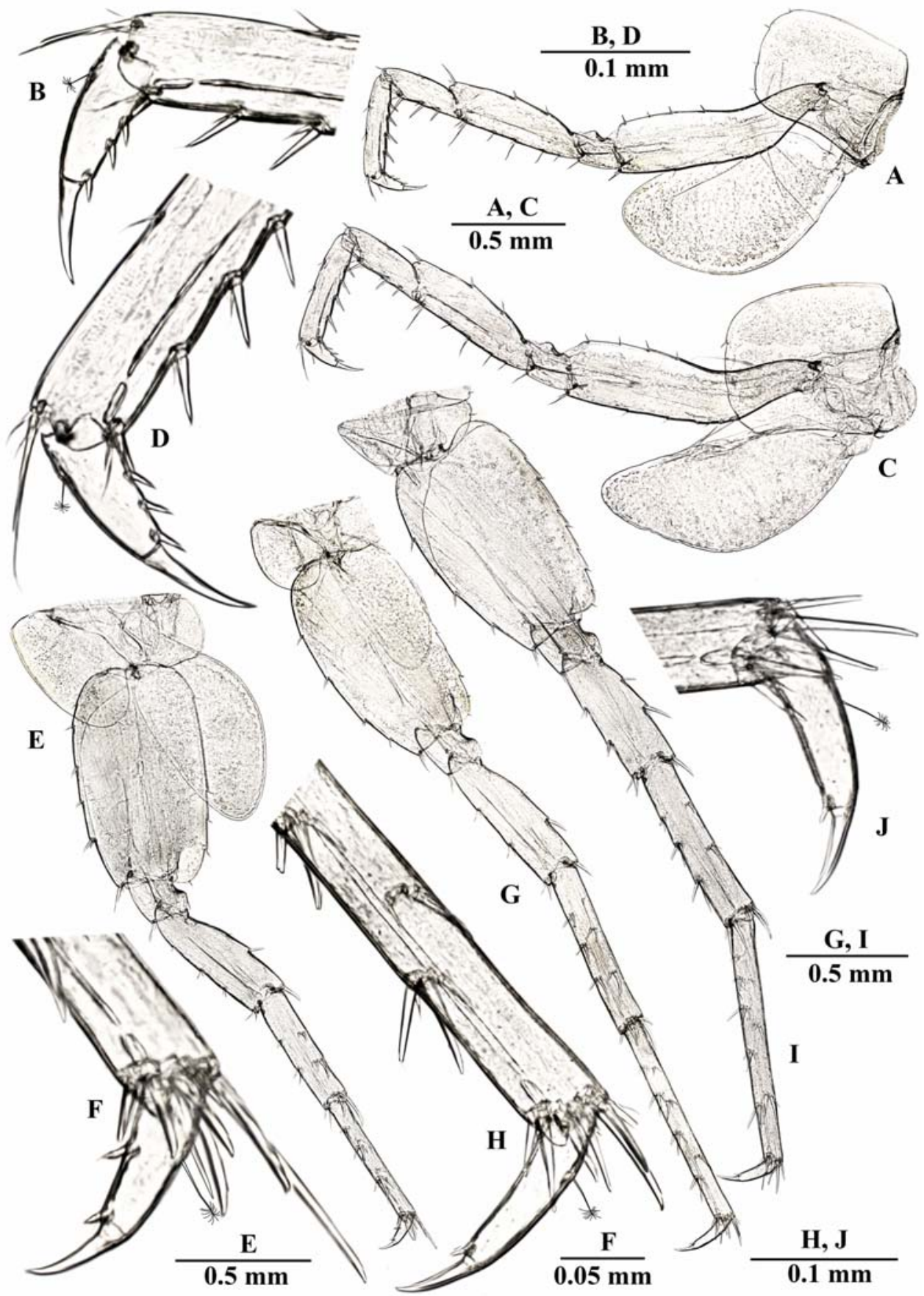

Fig. 5. Niphargus hrabei S. Karaman, 1932, O': A — pereopod III; B — dactylus of PIII; C - pereopod IV; D - dactylus of PIV; E - pereopod V; F - dactylus of PV; G - pereopod VI; H - dactylus of PVI; I pereopod VII; J - dactylus of PVII.

Pис. 5. Niphargus hrabei S. Karaman, 1932, О’: А — переопод III; В - дактилус PIII; C - переопод IV; D — дактилус PIV; E — переопод V; F — дактилус PV; G — pereopod VI; H — dactylus PVI; I переопод VII; J — дактилус PVII. 




Fig. 6. Niphargus hrabei S. Karaman, 1932, O' (A-D, F, H, J-L) and ${ }_{+}(\mathrm{E}, \mathrm{G}, \mathrm{I})$ : A-C - epimeral plates I-III; D, E — uropod I; F, G — uropod II; H, I — uropod III; J — telson; K — pleopod III; L — retinacle of pleopod III.

Pис. 6. Niphargus hrabei S. Karaman, 1932, О7 (A-D, F, H, J-L) и 9 (Е, G, I): А-C - эпимеральные пластинки I-III; D, E — уропод I; F, G - уропод II; H, i — уропод III; J — тельсон; $\mathrm{K}$ — плеопод III; $\mathrm{L}$ - ретинакула плеопод III. 




Fig. 7. Niphargus hrabei S. Karaman, 1932, o: A — gnathopod I; B — gnathopod II; C — pereopod III; D pereopod IV; E - pereopod V; F — pereopod VI; G - pereopod VII; H - telson.

Рис. 7. Niphargus hrabei S. Karaman, 1932, + : А — гнатопод I; В — гнатопод II; C — переопод III; D переопод IV; E — переопод V; F — переопод VI; G — переопод VII; H — тельсон. 
posterior margin; posteroventral angle tapered into a spike. Epimeral plate III: posterior margin distinctly oblique, ventral margin slightly convex; with 3 spiniform setae along ventral margin; with 7 setae along posterior margin; posteroventral angle tapered into a spike.

UROSOMITES (Fig. 13A): urosomite I with 1 spine accompanying 1-2 simple seta on each side dorsolaterally, with 1 posteroventral spines near basis of uropod I; urosomite II with 1 spine accompanying 1 simple seta on each side dorsolaterally, urosomite III unarmed.

COXAE (Figs 3D, G; 5A, C, E, G, I; 7A-G): ratio of width/depth of coxal plates I-IV are 1.2/ $1,1.3 / 1,1.2 / 1$ and $1.2 / 1$, respectively; coxal plate I oval, with rounded anteroventral corner, armed with 3 marginal and 1 submarginal setae, anterior margin of coxal plate II with 3 marginal and 1 submarginal setae; anterior margins of coxal plates III and IV with 4 marginal setae, with rounded anteroventral corners; coxal plates V-VI with large lobes anteriorly, posterior margins with 1 setae each; anterior margins with 1-3 and 0 setae respectively; coxal plate VII trapezoid, with concave ventral margin; posterior lobe with 1 seta; coxal gills II-VI ovoid, in males ratio of gills/bases of pereopod are 1/1, 1/ $1,1 / 1,0.9 / 1,0.7 / 1$, respectively; in females $1.25 / 1,1.1 / 1,1.25 / 1,1.2 / 1,0.9 / 1$, respectively.

ANTENNA I (Fig. 3A): slender, about 0.50.55 of body length; peduncular articles moderately slender, ratio is $1 / 0.83 / 0.41$; flagellum consisting of 22-26 articles, most of them with 2 short aesthetascs each; accessory flagellum short, 2-articulated (Fig. 3B); ratio of antennas $\mathrm{I} / \mathrm{II}$ is $1 / 0.64$.

ANTENNA II (Fig. 3C): peduncular articles moderately stout, with several long setae along ventral and dorsal margins, dorsal setae shorter than inner ones; flagellum relatively short, consisting of 10-13 articles with relatively short setae; lengths of peduncle articles $4 / 5$ is $1 / 0.83$; flagellum is 0.8 of the length of peduncular articles $4+5$.

LABRUM (upper lip) (Fig. 4A): entire, longer than broad, with fine hair distally.

LABIUM (lower lip) (Fig. 4B): with entire, subrounded, wide apart, parallel outer lobes and well developed smaller inner lobes.
MANDIBLE (Fig. 4C-G). Left mandible: incisor with 5 teeth, lacinia mobilis with 4 teeth; with a row of 6 raker setae, few spatulate setae and one long seta at base of molar (Fig. 4G, F); ratio of mandibular palp article $2 / 3$ (distal) is $1 /$ 1-1.05; proximal article of palp without setae; article II with 8 setae; distal article with a group of 4 A-setae; 3 groups of B-setae; 16-18 Dsetae and 4-5 E-setae (Fig. 4E). Right mandible: incisor process with 5 teeth, lacinia mobilis toothed, with 7 teeth and a row of 6 raker setae (Fig. 4D).

MAXILLA I (Fig. 4H, I): inner lobe with 3 distal setae, outer lobe with 7 robust spines (6 spines with 1 strong lateral tooth each, inner spine with 2-3 small lateral teeth (1-1-1-1-11-3) (Fig. 4I)); palp 2-articulated, distal article with 6 simple setae distally.

MAXILLA II (Fig. 4J): both plates with numerous long distal simple setae, inner lobe with row of fine setae along inner margin.

MAXILLIPED (Fig. 4K): inner plate short, with 5 distal robust setae intermixed with 7 distal simple setae; outer plate reaching half of palpal article 2 and bearing a row of 17-18 distolateral spines and distal setae; palpal article 3 with 1 median and 1 distal bunches of setae at outer margin; palpal article 4 with 1 median seta at outer margin; nail shorter than pedestal, with a seta near basis.

GNATHOPOD I (Figs 3D-F; 7A): ischium with a group of 3 posterodistal setae; carpus is 0.45 of length of basis and 0.62 of length of propodus, with a single distal group of setae anteriorly, with transverse rows of setae along posterior margin and a row of setae posterolaterally; propodus subtrapezoidal, setose, with 58 rows of setae at posterior margin, anterior margin with 2 groups of total 6-7 setae each in addition to anterodistal group of 5-7 setae, several groups of short setae on inner surface, palmar corner armed with 1 long spiniform palmar seta, 3-4 serrated spiniform setae, single supporting spiniform seta on inner surface (Fig 4F-E); dactylus with 4-6 setae along anterior margin, with row of short setae along inner margin; length of nail is 0.3 of total length of dactylus. 
GNATHOPOD II (Figs 3G, H; 7B; 13D): ratio of length/width of basis is $0.33 / 1$, with 5 dorsolateral setae; ischium with $2-4$ posterodistal setae; carpus is 0.45 of length of basis and 0.68 of length of propodus, with distal group of setae anteriorly, with row of seta along posterior margin and a row of seta posterolaterally; propodus subtrapezoidal, setose, larger than propodus of $\mathrm{GnI}(\mathrm{GnI} / \mathrm{II}$ as $0.9 / 1)$, posterior margin with $6-8$ rows of setae, anterior margin with a group of 2 setae in addition to 5-8 anterodistal setae, with several groups of setae on inner surface, palmar corner with 1 strong palmar spiniform seta, single supporting spiniform seta on inner surface and 2 denticulated thick spiniform setae on outer side (Figs 3H; 13D); dactylus with 4-5 setae along anterior margin and few short setae along inner margin; the length of nail is about 0.27 of total length of dactylus.

PEREOPODS III-IV (Figs 5A-D; 7C, D) almost similar in size and shape;

PEREOPOD III (Figs 5A, B; 7C): basis is 3.7-3.9 times as long as wide, with posterior margin bearing long marginal setae, with distoventral group of setae; ischium short, rectangular, with distoventral group of setae; merus with slender simple setae along dorsal and ventral margins; ratio of carpus/propodus is 0.84 0.85 ; propodus with 4 groups of spines along ventral margin; dactylus relatively stout, curved, sharp distally, with 3 additional ventral spines and 1 median short plumose seta at outer margin (Fig. 5B); length of nail is $0.42-0.43$ of total length of dactylus; ratio of dactyli of PpIII/IV is $1.1 / 1$.

PEREOPOD IV (Figs 5C, D; 7D): basis is 3.9-4.1 times as long as wide, with posterior margin bearing long marginal setae, with distoventral group of setae; ischium short, rectangular, with distoventral group of setae; merus with slender simple setae along dorsal and ventral margins; ratio of carpus/propodus is $0.76-$ 0.81 ; propodus with 4 groups of spines along ventral margin; dactylus relatively stout, curved, sharp distally, with 3 additional ventral spines and 1 median short plumose seta at outer margin (Fig. 5D); length of nail is $0.42-0.43$ of total length of dactylus.
PEREOPODS V-VII (Figs 5E, G, I; 7E, F, $\mathrm{G})$ : ratio of lengths of $\mathrm{PpV} / \mathrm{VI} / \mathrm{VII}$ is $1 / 1.43$ / 1.44 .

PEREOPOD V (Figs 5E, F; 7E): ratio of length/width of basis is $1 / 0.6$, almost rectangular, with distinct posteroventral lobe; posterior margin straight, with a row of 14 slender marginal setae; anterior margin convex, with a row of 6 slender marginal setae, which distinctly longer than posterior ones, and a group of setae in distal part; ischium subquadrate; merus with 3 bunches of slender spines along dorsal margin and with 1 spine on ventral margin; propodus slender, 8 times as long as wide, with several bunches of short spines; dactylus (Fig. 5F) with 2 small additional ventral spines and 1 median short plumose seta at outer margin.

PEREOPOD VI (Figs 5G, H; 7F): ratio of length/width of basis is $1 / 0.56-0.6$, with distinct posteroventral lobe and slightly concave or straight posterior margin, bearing a row of 8-10 short marginal setae; anterior margin convex, with a row of 4-6 marginal setae; merus with several bunches of short spines along dorsal and ventral margins; carpus with a group of spines intermixed with single short setae; propodus slender, about 7.5-11 times as long as wide, with several group of short spines; dactylus (Fig. 5H) slender, with 1 additional ventral spine and 1 short median plumose seta at outer margin.

PEREOPOD VII (Figs 5I, J; 7G): ratio of length/width of basis is $1 / 0.63$, with distinct posteroventral lobe and slightly convex posterior margin bearing a row of 10-11 short marginal setae; anterior margin convex, with a row of 4 5 longer marginal setae; carpus with 3 groups of short spines along dorsal and 2 along ventral margins; propodus slender, about 9-11 times as long as wide, with several groups of short spines; dactylus (Fig. 5J) with a spine at inner margin, and a short median plumose seta at outer margin.

PLEOPODS (Fig. 6K): pleopod I with basal segment without setae, with 2 hooks in retinacle; pleopod II with basal segment armed with 1 large plumose setae and 2 coupling hooks in retinacle; pleopod III with basal segment armed 
with 4-8 medium and large sized plumose setae and 2 coupling hooks in retinacle (Figs 6L; $13 \mathrm{C})$.

UROPOD I (Fig. 6E, D): slightly different in males and females.

Male (Fig. 6D): protopodite longer than rami, 4 times as long as wide, with dorsointernal row of 4 spiniform setae and 2 subdistal spines, dorsoexternal row of 3 spines and characteristic spoon-shaped appendage distally; rami straight and subequal in length, endopodite not paddlelike, with 2 dorsolateral spines at inner surface and 2 mesial spines accompanying a single seta at outer surface, 4 apical spines; exopodite with 2 dorsal spines, 2 mesial groups consisting of 3 spines and a single seta each at outer surface, 4 apical spines.

Female (Fig. 6E): protopodite longer than rami, 4.9 times as long as wide, with dorsointernal row of 4 spiniform setae and 2 subdistal spines, dorsoexternal row of 3 spines, without spoon-shaped appendage; rami straight and subequal in length, endopodite not paddle-like, with 3 dorsolateral spines at inner surface and 4 mesial spines at outer surface, 4 apical spines; exopodite with 4 dorsal spines, 2 mesial groups consisting of 3 spines and a single seta each at outer surface and 4 apical spines.

UROPOD II (Fig. 6G, F): protopodite 2.83 times as long as wide, subequal rami; rami with lateral, mesial and distal slender spines, endopodite with 1-3 spines dorsolaterally and 1-3 spines ventrolaterally, 5 spines apically; exopodite with 2 spines dorsolaterally, 1-2 single spines mesially and 5 apically.

UROPOD III (Fig. 6H, I): similar in females and males; protopodite 1.9-2.2 times as long as wide, with 1-2 group of lateral spiniform setae and 6-7 apical spiniform setae; rami unequal, endopodite short, about 7.7-8.5 times shorter than exopodite, with a small simple seta an laterally and 1-2 spiniform setae apically; distal article is $0.22-0,24$ of length of proximal article, with 1-2 groups of thin-flexible setae along each margin and group of simple setae apically; proximal article with 5 groups of thin-flexible, plumose and spiniform setae along inner and outer margins.
TELSON (Figs $6 \mathrm{~J} ; 7 \mathrm{H}$ ): length/width ratio is $1 / 0.85-0.86$; cleft is $0.63-0.71$ of length of telson; margins straight or weakly rounded, narrowing apically; with variable armature, including 3 medium distal spines on each lobe, a lateral slender spine on each inner margins, $1-2$ slender lateral spines, accompanying by 2 plumose setae on each outer margins; dorsal surface with 2-4 small mesial setae, without spines; apical spiniform setae are $0.25-0.28$ of length of telson.

BODY SIZE. Females are significantly larger than males; the largest collected female has tbl. $10.0 \mathrm{~mm}$; the largest collected male has tbl. 5.0 $\mathrm{mm}$.

COLORATION. Body, appendages and internal organs are violet or blue-whitish (see Fig. 2A). The bright yellow eyespots are clearly visible on the head in males and females.

GENBANK ACCESSION NUMBERS. MW679705-MW679707.

TAXONOMIC REMARKS. Based on integrative taxonomy of the topotypic material of Niphargus cubanicus Birštein, 1954 it was found that this species is a junior synonym of $N$. hrabei S. Karaman, 1932 (see below). The original description of $N$. cubanicus, presented by Birštein (1954), is based only on one damaged female and two juveniles. Moreover, the distal segment of uropod III was damaged (regenerated) in the female, which led to the description of a new species by Birštein (1954: Fig. 2). At the same time, $N$. hrabei is well distinguished from all the epigean Caucasian representatives of the genus Niphargus in the following morphological features: 1) well pigmented, greenish or bluish, body (Fig. 2A); 2) the presence of 3 setae on outer lobe of maxilla I (Fig. 4H); 3 ) the absence of additional spines on dactyli of PpVIVII (Fig. 5); 4) the presence of lateral row of simple setae on basal segment of pleopod III (Fig. 6K); and 5) telson without dorsal spines (Fig. 6J).

ECOLOGY. In the Kuban riverbed, N. hrabei lives in channels (Fig. 2B) and small shallow, densely overgrown, well-warmed ponds. In the latter, the species was very abundant, with a large number of large mature individuals, 
which is probably due to the absence of large predators (e.g., fishes). Interestingly, the species is found only in the middle reaches of the Kuban River, where other epigean species of the genus Niphargus are absent.

DISTRIBUTION. Niphargus hrabei was firstly recorded from the basin of the Kuban River (Krasnodar region), as well as the Russian Federation (Fig. 1). Previously, the species was recorded from the floodplains and lowlands of the Danube, south-eastern Germany, Croatia, Hungary, Serbia, south-eastern Romania and the south-western part of Ukraine (Cărăuşu et al., 1955; Nesemann et al., 1995; Copilaş-Ciocianu et al., 2014, 2017).

\section{Niphargus potamophilus Birštein, 1954}

Figs $2 \mathrm{C} ; 8-12 ; 13 \mathrm{E}-\mathrm{G}$. fig. 1 .

Niphargus potamophilus Birštein, 1954: 1025-1028,

MATERIAL EXAMINED. NEOTYPE, $\sigma^{7}$ (bl. $11 \mathrm{~mm}$ ), ZMMU Mb-1176, Russia, Rostov Region, Aksaysky District, a canal in the floodplain of the Don River, near the Olginskaya village, $47^{\circ} 14.034^{\prime} \mathrm{N}, 39^{\circ} 52.894^{\prime} \mathrm{E}$, about $1 \mathrm{~m}$ above sea level, hand net sampling, 18 May 2019, coll. I. Marin \& D. Palatov.

Other materials: + (bl. $8 \mathrm{~mm}$ ), ZMMU Mb1177, Russia, Rostov Region, Aksaysky District, same locality, collectors and data as neotype; $50^{7} \sigma^{7}$ ?, 7 우, Russia, Rostov Region, Aksaysky District, same locality, collectors and data as neotype; $2 \sigma^{7} \sigma^{7}, 7$, 9 , Russia, Krasnodar Krai, Anapa Urban okrug, a small pond in the Utash village, $45^{\circ} 06.06^{\prime} \mathrm{N}, 37^{\circ} 17.56^{\prime} \mathrm{E}$, about 3 $\mathrm{m}$ above sea level, hand net sampling, 18 May 2019, coll. I. Marin \& D. Palatov; $70^{7} \sigma^{7}, 25$ 웅, Russia, Krasnodar Krai, Anapa Urban okrug, a small pond in the floodplain of the Staraya Kuban River, $45^{\circ} 8.797^{\prime} \mathrm{N}, 37^{\circ} 18.705^{\prime} \mathrm{E}$, about $0 \mathrm{~m}$ above sea level, hand net sampling, 10 May

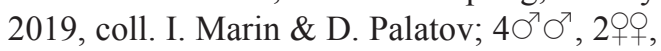
Russia, Krasnodar Krai, Krymsky District, a canal in the floodplain of the Checkups River, near Chekon village, $45^{\circ} 8.942^{\prime} \mathrm{N}, 37^{\circ} 31.842^{\prime} \mathrm{E}$, about $1 \mathrm{~m}$ above sea level, hand net sampling, 10 May 2019, coll. I. Marin \& D. Palatov; $10^{7}$, 6 우, Russia, Krasnodar Krai, Krymsky District, a small pond near the Novotroitsky village, $45^{\circ}$ $01.716^{\prime} \mathrm{N}, 38^{\circ} 00.722^{\prime} \mathrm{E}$, about $4 \mathrm{~m}$ above sea level, hand net sampling, 18 May 2019, coll. I. Marin \& D. Palatov; $2+\circ$, Russia, Krasnodar Krai, Slavyansky District, boggy pond in the Slavyansk-na-Kubani town, $45^{\circ} 13.898^{\prime} \mathrm{N}$, $38^{\circ} 06.789^{\prime} \mathrm{E}$, about $5 \mathrm{~m}$ above sea level, hand net sampling, 18 May 2019, coll. I. Marin \& D. Palatov.

\section{DESCRIPTION.}

BODY: yellowish, moderately slender.

HEAD: without rostrum, with yellow pigmented spots close to anterior lobe and with subrounded lateral cephalic lobes and excavated anteroventral sinus.

PEREON: pereonites I-VII without setae, smooth.

PLEOSOMA: pleonites I-III with several short marginal setae on each posterodorsal margin.

EPIMERAL PLATES (Fig. 11A-C): posteroventral corners of epimeral plates I-III with significantly produced acute posteroventral corners. Epimeral plate I: ventral margin almost straight, posterior margin slightly convex; without spines along ventral margin; with 4 setae along posterior margin; posteroventral angle tapered into a spike. Epimeral plate II: posterior margin slightly convex, ventral margin distinctly convex; with a spiniform seta on ventral margin; 5 setae along posterior margin; posteroventral angle tapered into a spike. Epimeral plate III: posterior margin oblique, ventral margin slightly convex; with a spiniform seta on ventral margin; with 3 setae along posterior margin; posteroventral angle tapered into a spike.

UROSOMITES (Fig. 13G): urosomite I with 2 spines on each side dorsolaterally, with 1 posteroventral spines near basis of uropod I; urosomite II with 1 spine on each side dorsolaterally, urosomite III unarmed.

COXAE. Male (Figs 8D, F; 10A, C, E, G, I): ratio of width/depth of coxal plates I-IV are 1/ $0.92,1 / 0.86,1 / 0.82$ and $1 / 1$, respectively; coxal plate I oval, with rounded anteroventral corner, armed with 5 marginal and 1 submarginal setae, anterior margin of coxal plate II with 5 marginal and 1 submarginal setae; anterior margins of 

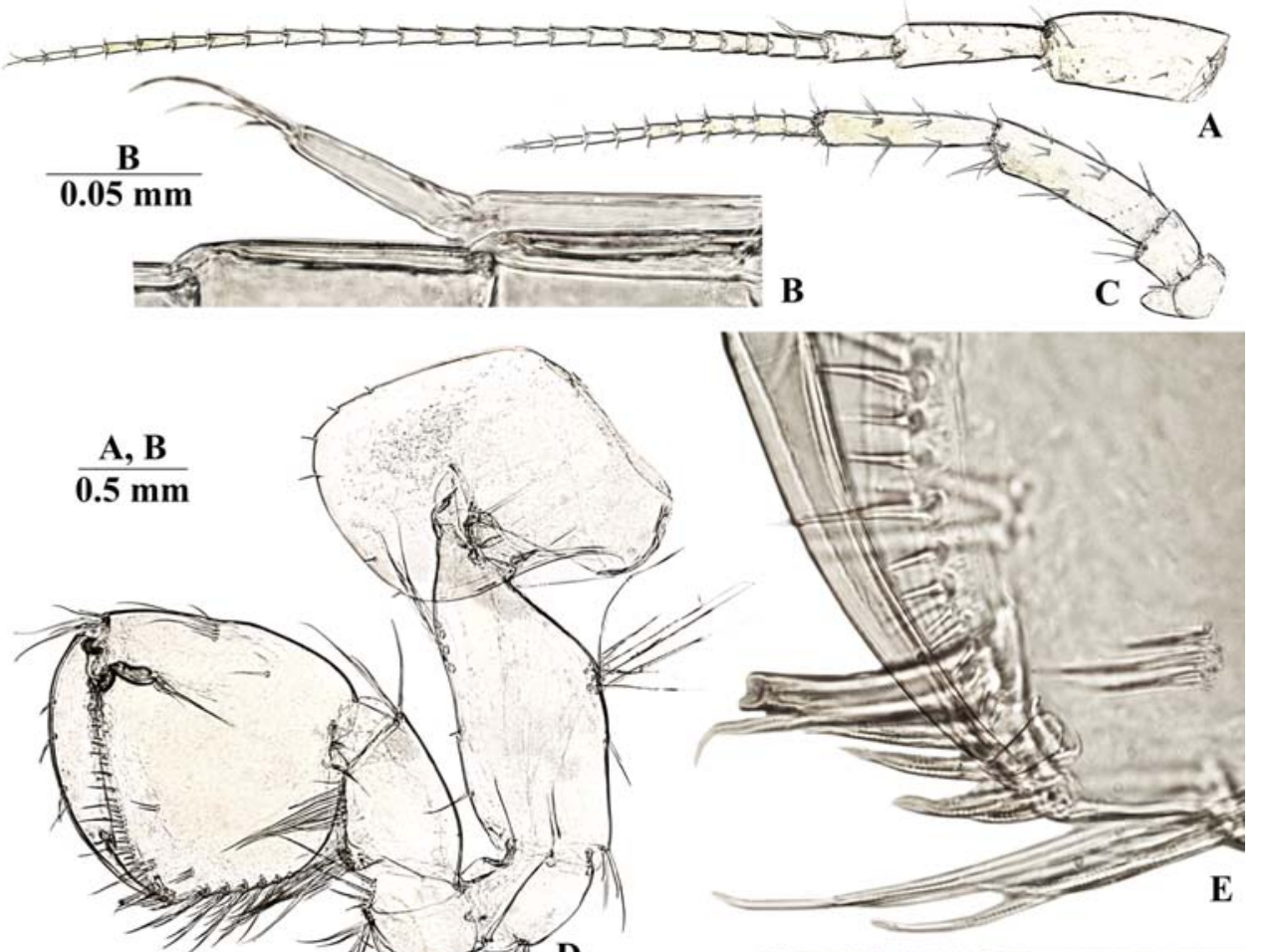

D, F
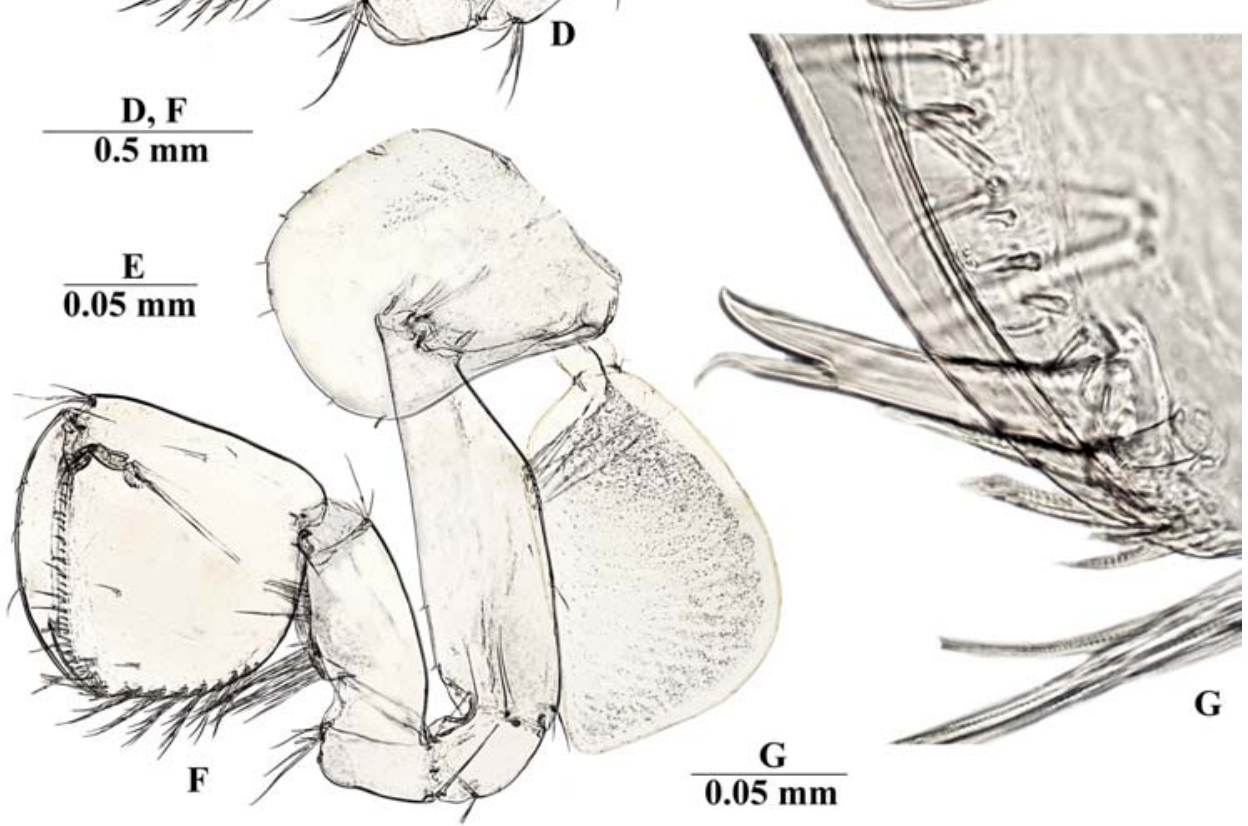

Fig. 8. Niphargus potamophilus Birštein, 1954, O’: A — antenna I; B - accessory flagellum of AI; C antenna II; D - gnathopod I; E - distoventral corner of palmar margin of chela of GnI; F - gnathopod II; G - distoventral corner of palmar margin of chela of GnII.

Pис. 8. Niphargus potamophilus Birštein, 1954, О': A — антенна I; В - добавочный жгутик AI; C антенна II; D - гнатопод I; E - дистовентральный угол клешни GnII; F — гнатопод II; G дистовентральный угол клешни GnII. 




Fig. 9. Niphargus potamophilus Birštein, 1954, O': A — upper lip; B — lower lip; C, E - mandible; D, F incisor process and pars incisiva of mandible; $\mathrm{G}$ - maxilla I; H — same, distal margin of outer lobe; I maxilla II; J - maxilliped.

Pис. 9. Niphargus potamophilus Birštein, 1954, Оج: А — верхняя губа; В - нижняя губа; С, Е мандибула; D, F - режущий отросток и pars incisiva мандибул; G — максилла I; H - то же, дистальный край внешней доли; I — максилла II; J — максиллипед. 




Fig. 10. Niphargus potamophilus Birštein, 1954, Oج: A — pereopod III; B — dactylus of PIII; C - pereopod IV; D - dactylus of PIV; E - pereopod V; F - dactylus of PV; G - pereopod VI; H - dactylus of PVI; I - pereopod VII; J - dactylus of PVII.

Pис. 10. Niphargus potamophilus Birštein, 1954, О: А — переопод III; В - дактилус PIII; C - переопод PIV; D — дактилус PIV; E — переопод V; F — дактилус PV; G — переопод VI; H — дактилус PVI; I - переопод VII; J — дактилус PVII. 


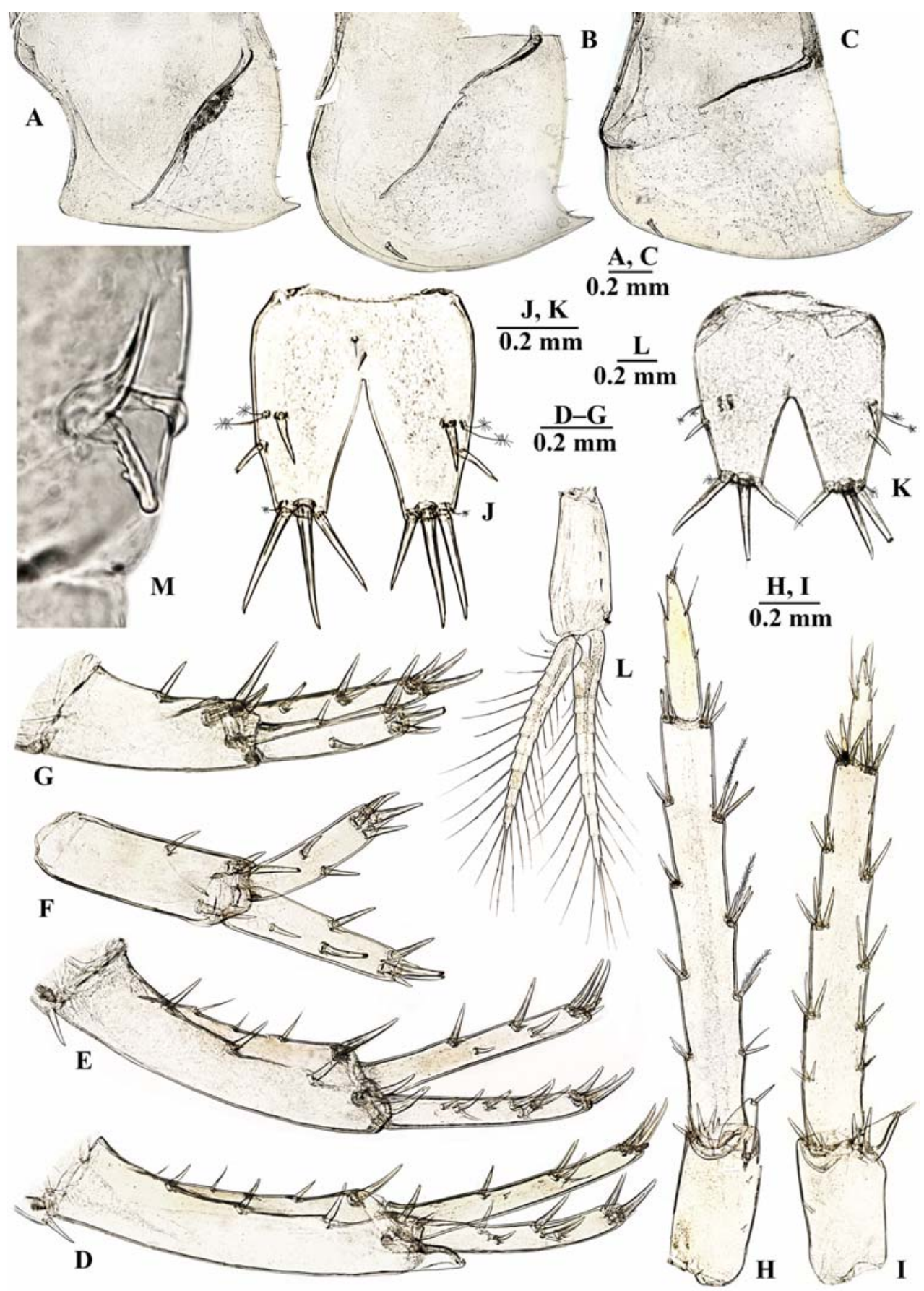

Fig. 11. Niphargus potamophilus Birštein, 1954, O (A-D, F, H, J, L, M) and + (G, E, I): A-C - epimeral plates I-III; D-E — uropod I; F, G — uropod II; H, I — uropod III; J, K — telson; L — pleopod III; M retinacle of pleopod III.

Pис. 11. Niphargus potamophilus Birštein, 1954, О7 (A-D, F, H, J, L, M) и $+(\mathrm{G}, \mathrm{E}, \mathrm{I}): \mathrm{A}-\mathrm{C}-$ эпимеральные пластины I-III; D-E - уропод I; F, G - уропод II; H, I - уропод III ; J, K — тельсон; $\mathrm{L}$ — плеопод III; M — ретинакула плеопод III. 


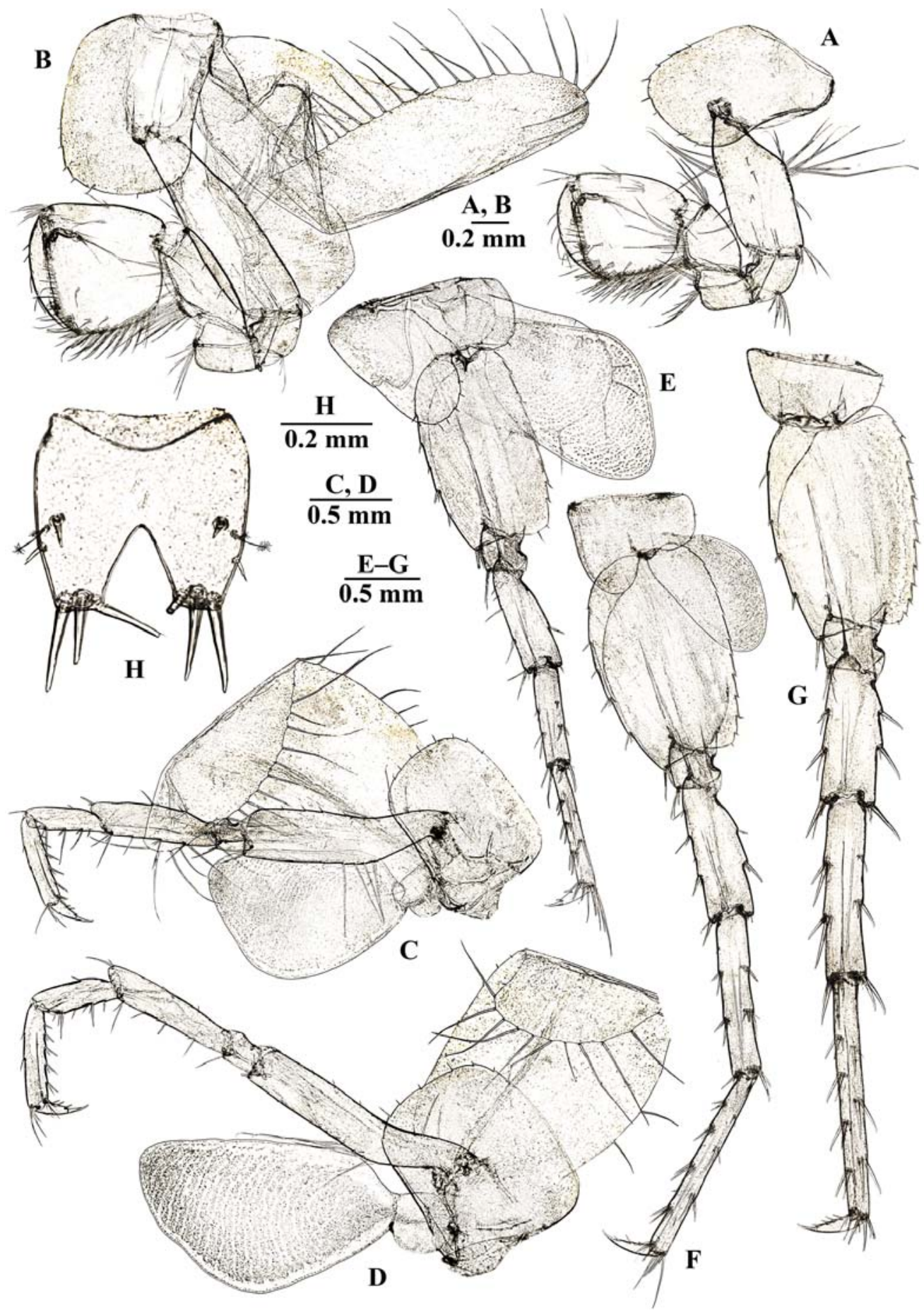


III; D — pereopod IV; E — pereopod V; F - pereopod VI; G — pereopod VII.

Рис. 12. Niphargus potamophilus Birštein, 1954, + : А — гнатопод II; В — гнатопод II; C — переопод III; D — переопод IV; E — переопод V; F — переопод VI; G — переопод VII. 



Fig. 13. External morphology of Niphargus hrabei S. Karaman, 1932 (A-D) and N. potamophilus Birštein, 1954 (e-g): A, G - urosome; B - head; C - coupling hook of retinacle; D — distoventral corner of palm of GnII; E, F - spoon-shaped process of uropod I in males.

Рис. 13. Внешняя морфология Niphargus hrabei S. Karaman, 1932 (A-D) и N. potamophilus Birštein, $1954(\mathrm{E}-\mathrm{G}): \mathrm{A}, \mathrm{G}$ - уросома; В — голова; C — крючки ретинакулы; D — дистовентральный угол ладони клешни GnII; E, F — ложкообразный придаток уропод I самцов. 
coxal plates III and IV with rounded anteroventral corners, 5 and 6 marginal setae, respectively; coxal plates V-VI with large lobes anteriorly, posterior margins with 2 and 2-3 setae, respectively; anterior margins with 4 and 0 setae respectively; coxal plate VII trapezoid, with concave ventral margin; posterior lobe with 1 seta; coxal gills II-VI ovoid, ratio of gills/bases of pereopod are $1 / 1,1 / 1,1 / 1,0.9 / 1,0.6 / 1$, respectively. Female (Fig. 12A-G): ratio of width/depth of coxal plates I-IV are $0.8 / 1,0.8$ / $1,1.4 / 1$ and $0.8 / 1$, respectively; coxal plate I oval, with rounded anteroventral corner, armed with 8 marginal and 1 submarginal setae, anterior margin of coxal plate II with 8 marginal setae; anterior margins of coxal plates III and IV with rounded anteroventral corners, 10 and 8 marginal setae, respectively; coxal plates V-VI with large lobes anteriorly, posterior margins with 2 and 2-3 setae, respectively; anterior margins with 6-7 and 0 setae respectively; coxal plate VII trapezoid, with concave ventral margin; posterior lobe with 1 seta; coxal gills II-VI ovoid, ratio of gills/bases of pereopod are $1.3 / 1,1 / 1,1.2 / 1,1.1 / 1,0.7 / 1$, respectively.

ANTENNA I (Fig. 8A): slender, about 0.50.55 of body length; peduncular articles moderately slender, ratio is $1 / 0.87 / 0.41$; flagellum consisting of 23-24 articles, most of them with 2 short aesthetascs each; accessory flagellum short, 2-articulated (Fig. 8B); ratio of antennas $\mathrm{I} / \mathrm{II}$ is $1 / 0.61$.

ANTENNA II (Fig. 8C): peduncular articles moderately stout, with several long setae along ventral and dorsal margins, dorsal setae slightly shorter than inner ones; flagellum relatively short, consisting of 11 articles with relatively short setae; lengths of peduncle articles $4 / 5$ is $1 /$ 0.94 ; flagellum is 0.84 of the length of peduncular articles $4+5$.

LABRUM (upper lip)(Fig. 9A): entire, longer than broad with fine hair distally.

LABIUM (lower lip) (Fig. 9B): with entire, subrounded, wide apart, parallel outer lobes and well developed smaller inner lobes.

MANDIBLE (Fig. 9C-F). Left mandible: incisor with 5 teeth, lacinia mobilis with 4 teeth; with a row of 8 raker setae, few spatulate setae and one long seta at base of molar (Fig. 9C, D); ratio of mandibular palp article $2 / 3$ (distal) is $1 /$ 1-1.03; proximal article of palp without setae; article II with 7-8 setae; distal article with a group of 4 A-setae; 2 groups of B-setae; 19-20 D-setae and 4-5 E-setae. Right mandible: incisor process with 4 teeth, lacinia mobilis mobilis toothed, with 7 teeth and with a row of 8 raker setae (Fig. 9F, E).

MAXILLA I (Fig. 9G, H): inner lobe with 1 distal seta, outer lobe with 7 robust spines (6 spines with 1 robust spiniform seta each, inner spine with 2-3 small lateral teeth (1-1-1-1-11-3) (Fig. 4I)); palp 2-articulated, distal article with 4 simple setae distally.

MAXILLA II (Fig. 9I): both plates with numerous long distal simple setae, inner lobe with row of fine setae along inner margin.

MAXILLIPED (Fig. 4K): inner plate short, with 2-3 distal robust setae intermixed with 5 distal simple setae; outer plate reaching half of palpal article 2 and bearing a row of 14-15 distolateral spines and distal setae; palpal article 3 with 1 median and 1 distal bunches of setae at outer margin; palpal article 4 with 1 median seta at outer margin; nail shorter than pedestal, with 2 setae near basis.

GNATHOPOD I (Figs 8D, E; 12A): ischium with a group of 5-7 posterodistal setae; carpus is $0.41-0.42$ of length of basis and $0.53-$ 0.58 of length of propodus, with a single distal group of setae anteriorly, with transverse rows of setae along posterior margin and a row of setae posterolaterally; propodus subtrapezoidal, setose, with 6-8 rows of setae at posterior margin, anterior margin with 2 groups of total 2-7 setae each in addition to anterodistal group of 5-6 setae, several groups of short setae on inner surface, palmar corner armed with 1 long spiniform palmar seta, 3 serrated spiniform setae, single supporting spiniform seta on inner surface (Fig 8E); dactylus with 3-6 setae along anterior margin, with row of short setae along inner margin; length of nail is 0.3 of total length of dactylus.

GNATHOPOD II (Figs 8F, G; 12B): ratio of length/width of basis is $0.41-0.45 / 1$, with $2-3$ dorsolateral setae; ischium with $2-3$ posterodis- 
tal setae; carpus is $0.44-0.47$ of length of basis and $0.67-0.76$ of length of propodus, with distal group of setae anteriorly, with row of seta along posterior margin and a row of seta posterolaterally; propodus subtrapezoidal, setose, larger than propodus of $\mathrm{GnI}$ (ratio of $\mathrm{GnI} / \mathrm{II}$ is $0.9 / 1$ ), posterior margin with $7-9$ rows of setae, anterior margin without setae, not counting group of 5-8 anterodistal setae, with several groups of setae on inner surface, palmar corner with 1 strong palmar spiniform seta, single supporting spiniform seta on inner surface and 2-3 denticulated thick spiniform setae on outer side (Fig. 8G); dactylus with 3-5 setae along anterior margin and few short setae along inner margin; the length of nail is about 0.27 of total length of dactylus.

PEREOPODS III-IV (Figs 10A-D; 12C, D) almost similar in size and shape.

PEREOPOD III (Figs 10A, B; 12C): basis is 3.7-3.9 times as long as wide, with posterior margin bearing long marginal setae, with distoventral group of setae; ischium short, rectangular, with distoventral group of setae; merus with slender simple setae along dorsal and ventral margins; ratio of carpus/propodus is $0.77-$ 0.83 ; propodus with $5-6$ groups of spines along ventral margin; dactylus relatively stout, curved, sharp distally, with 3 additional ventral spines and 1 median short plumose seta at outer margin (Fig. 10B); length of nail is $0.37-0.43$ of total length of dactylus; ratio of dactyli of PpIII/IV is $1.1 / 1$.

PEREOPOD IV (Figs 10C, D; 12D): basis is 3.8-5.3 times as long as wide, with posterior margin bearing long marginal setae, with distoventral group of setae; ischium short, rectangular, with distoventral group of setae; merus with slender simple setae along dorsal and ventral margins; ratio of carpus/propodus is 0.78 0.80 ; propodus with 5 groups of spines along ventral margin; dactylus relatively stout, curved, sharp distally, with 3 additional ventral spines and 1 median short plumose seta at outer margin (Fig. 10D); length of nail is $0.38-0.42$ of total length of dactylus.

PEREOPODS V-VII (Figs 10E, G, I; 12E$\mathrm{G})$ : ratio of the lengths of $\mathrm{PpV} / \mathrm{VI} / \mathrm{VII}$ is $1 / 1.38$ / 1.42 .
PEREOPOD V (Figs 10E, F; 12E): ratio of length/width of basis is $1 / 0.58-0.62$, with distinct posteroventral lobe; posterior margin straight or slightly convex, with a row of 10 slender marginal setae; anterior margin convex, with a row of 4-6 slender marginal setae, which distinctly longer than posterior ones, and a group of setae in distal part; ischium subquadrate; merus with 3-4 bunches of slender spines along dorsal margin and with 1 spine on ventral margin; propodus slender, 7.7-8.3 times as long as wide, with several bunches of short spines; dactylus (Fig. 10F) with 2 small additional ventral spines and 1 median short plumose seta at outer margin.

PEREOPOD VI (Figs 10G, H; 12F): ratio of length/width of basis is $1 / 0.6-0.65$, with distinct posteroventral lobe and slightly convex or straight posterior margin, bearing a row of 10 12 short marginal setae; anterior margin convex, with a row of 4-5 groups of marginal setae; merus with several bunches of short spines along dorsal and ventral margins; carpus with a group of spines intermixed with single short setae; propodus slender, about 8.8-10.4 times as long as wide, with several group of short spines; dactylus (Fig. 10H) slender, with 3-4 additional ventral spine and 1 short median plumose seta at outer margin.

PEREOPOD VII (Figs 10I, J; 12G): ratio of length/width of basis is $1 / 0.63-0.67$, with posteroventral lobe and slightly convex posterior margin bearing a row of 9-12 short marginal setae; anterior margin convex, with a row of 34 longer marginal setae; carpus with 2-3 groups of short spines along dorsal and 2 along ventral margins; propodus slender, about 8.5-9.5 times as long as wide, with several groups of short spines; dactylus (Fig. 10J) with 3-4 spines at inner margin and a short median plumose seta at outer margin.

PLEOPODS (Fig. 11L): pleopod I and II with basal segment without setae, with 2 hooks in retinacle; pleopod III with basal segment armed 3 small sized simple setae and 2 coupling hooks in retinacle (Fig. 11M).

UROPOD I (Fig. 11E, D): slightly different in males and females. 
Male (Fig. 11D): protopodite longer than rami, 4.5 times as long as wide, with dorsointernal row of 3 spiniform setae and 2 subdistal spines, dorsoexternal row of 4 spines and setae and characteristic spoon-shaped appendage distally (Fig. 13E, F); rami straight and subequal in length, endopodite not paddle-like, with 2 dorsolateral and 2 mesial spines accompanying a single seta, 4 apical spines; exopodite with 2 mesial spines and 2 dorsomesial groups consisting of 2 spines and a single seta each, 4 apical spines.

Female (Fig. 11E): protopodite longer than rami, 4.1 times as long as wide, with dorsointernal row of 3 spiniform setae and 2 subdistal spines, dorsoexternal row of 4 setae and a spine, without spoon-shaped appendage; rami straight and subequal in length, endopodite not paddlelike, with 2 dorsal and 2 mesial spines at outer surface, 4 apical spines; exopodite with 3 dorsal spines, 2 mesial groups consisting of $2-3$ spines and a single seta each at outer surface and 4 apical spines.

UROPOD II (Fig. 11G, F): protopodite 2.63.3 times as long as wide, subequal rami; rami with lateral, mesial and distal slender spines, endopodite with 1-3 spines dorsolaterally and $0-1$ spines ventrolaterally, 5 spines apically; exopodite with 1-2 spines dorsolaterally, 0-1 single spines mesially and 5 apically.

UROPOD III (Fig. 11H, I): similar in females and males; protopodite 1.7-1.9 times as long as wide, with 1-2 lateral spiniform setae and 6-8 apical spiniform setae; rami unequal, endopodite short, about 8.9-9.6 times shorter than exopodite, with one spiniform seta apically; distal article is $0.28-0,35$ of length of proximal article, with 1-2 groups of thin-flexible setae along each margin and group of simple setae apically; proximal article with 4 groups of thin-flexible, plumose and spiniform setae along inner and outer margins.

TELSON (Figs 11J, K; 12H): ratio of length/ width is $1 / 0.95-0.96$ in males and $1 / 1.1$ in females; cleft is $0.59-0.61$ of length of telson in males and 0.40-0.42 in females; margins straight or weakly rounded, narrowing apically; with variable armature, including 3 medium size distal spines on each lobe, one dorsal spine and one slender lateral spines, accompanying by 2 plumose setae on each outer margins; dorsal surface with 2-3 small mesial setae, without spines; apical spiniform setae are $0.5-0.53$ of length of telson.

BODY SIZE. Females are equal in size to males; the largest collected female has tbl. 9.0 $\mathrm{mm}$; the largest collected male has tbl. $10.0 \mathrm{~mm}$.

COLORATION. Body, appendages and internal organs are yellowish (Fig. 2C). Bright yellow eyespots are clearly visible on the head both in males and in females.

GENBANK ACCESSION NUMBERS. MW679708-MW679711.

TAXONOMIC REMARKS. Niphargus potamophilus is morphologically, but not phylogenetically, close to $N$. hrabei (see above), from which the former can be distinguished by: 1) more elongated body than in N. hrabei (Fig. $2 \mathrm{C})$; 2) yellowish pigmentation of body (Fig. 2C); 3) the presence of 1 setae on outer lobe of maxilla (Fig. 9G); 4) the presence of additional spines on dactyli of PpVI-VII (Fig. 10);5) the absence of lateral row of simple setae on basal segment of pleopod III (Fig. 11L); and 6) telson with well-developed dorsal and submarginal spines (Figs 11J, K; 12H).

From related N. valachicus (see below), it can be differentiated by: 1) less produced posteroventral margins of epimeral plates I-III(Fig. $11 \mathrm{~A}-\mathrm{C})$; 2) the presence of 2 spines on each posterodorsal margins of urosomite I and 1 spine - on urosomite II (Fig. 13G) (vs. 1 spine on urosomite I and 1 spine on urosomite II in $N$. valachicus); 3) shape of GnI-II, which are almost quadrate (the width equal to the depth) in $N$. potamophilus (Fig. 8D, F), while their width is significantly less than depth in N. valachicus (Fig. 14D, E); 4) the armature of dactyli of PpIII-VII with only 2-3 additional spines in $N$. potamophilus (Fig. 10) vs. 4-6 spines in $N$. valachicus (Fig. 16); and 5) stouter telson (Figs $11 \mathrm{~J}, \mathrm{~K} ; 12 \mathrm{H})$ (vs. more elongated and triangular in shape in $N$. valachicus (Fig. 17H, I)).

From N. magnus (see below), which is also phylogenetically related to $N$. potamophilus, the latter species can be separated by: 1) stouter 
body (Figs $11 \mathrm{~J}, \mathrm{~K} ; 12 \mathrm{H}$ ); 2) more produced posteroventral margins of epimeral plates I-III (Fig. 11A-C); 3) the presence of 2 spines on each posterodorsal margins of urosomite I and 1 spine - on urosomite II (Fig. 13G) (vs. 1 spines + several simple setae on urosomite I and 3 spines on urosomite II in N. magnus); 4) the armature of dactyli of PpIII-VII (only 2-3 additional spines in $N$. potamophilus (Fig. 10) vs. 4 spines in N. magnus (Fig. 20)); 5) equal rami of uropod I in males (Fig. 11D) (vs. unequal in males of $N$. magnus (Fig. 21D)); 6) similar uropod III in males and females (Fig. 11H, I) (vs. different, with elongated outer rami in males in N. magnus (Fig. 21H, I)).

ECOLOGY. Like N. hrabei (see above), $N$. potamophilus lives in channels and small shallow, densely overgrown, well-warmed ponds (Fig. 2D, E) only in the lower reaches of the Don and Kuban rivers (Fig. 1), where other epigean species of the genus Niphargus are absent. The species is also more common and abundant in ponds where a large number of mature individuals are present, probably due to the absence of large predators (e.g., fishes).

DISTRIBUTION. The species was originally described from the Don River delta near Rostov-on-Don (Birštein, 1954), and was firstly recorded from the basin of the Kuban River (Fig. 1).

\section{Niphargus valachicus Dobreanu et Manolache, 1933 \\ Figs 14-17.}

Niphargus valachicus Dobreanu et Manolache, 1933: 104-106, fig. 2-4.

Niphargus mediodanubialis Dudich, 1941: 61-64, figs $1-2$.

MATERIAL EXAMINED. $\sigma^{7}$ (bl. $\left.11 \mathrm{~mm}\right)$, ZMMU Mb-1179, Georgia, Samegrelo-Zemo Svaneti, Khobi Municipality, small pond near road Chaladidi-Kulevi-Poti, $42^{\circ} 11^{\prime} 42.0^{\prime \prime} \mathrm{N}$, $41^{\circ} 42^{\prime} 19.9^{\prime \prime} \mathrm{E}$, about $2 \mathrm{~m}$ above sea level, hand net sampling, 30 Jan 2019, coll. I. Marin \& V. Maslova.

DESCRIPTION.

HEAD: without rostrum, with yellow-pigmented spots close to anterior lobe and with subrounded lateral cephalic lobes and excavated anteroventral sinus.

PEREON: pereonites I-VII without setae, smooth.

PLEOSOMA: pleonites I-III with several short marginal setae on each posterodorsal margin.

EPIMERAL PLATES (Fig. 17A-C): posteroventral corners of epimeral plates I-III with significantly produced acute corners. Epimeral plate I: ventral margin almost straight, posterior margin slightly convex; without spines along ventral margin; with 7 setae along posterior margin; posteroventral angle tapered into a spike. Epimeral plate II: posterior margin slightly convex, ventral margin distinctly convex; with a spiniform seta on ventral margin; 9 setae along posterior margin; posteroventral angle tapered into a spike. Epimeral plate III: posterior margin oblique, ventral margin slightly convex; with a spiniform seta on ventral margin; with 9 setae along posterior margin; posteroventral angle tapered into a spike.

UROSOMITES: urosomite I with 1 spine accompanying 1-2 simple seta on each side dorsolaterally, with 1 posteroventral spines near basis of uropod I; urosomite II with 1 spine accompanying 1 simple seta on each side dorsolaterally, urosomite III unarmed.

COXAE (Figs 14D, E; 16A, C, E, G, I): ratio of width/depth of coxal plates I-IV are 1/0.73, $1 / 0.74,1 / 0.8$ and $1 / 0.76$, respectively; coxal plate I oval, with rounded anteroventral corner, armed with 11 marginal and 1 submarginal setae, anterior margin of coxal plate II with 12 marginal setae; anterior margins of coxal plates III and IV with rounded anteroventral corners, 13 and 14 marginal setae, respectively; coxal plates V-VI with large lobes anteriorly, posterior margins with 2 setae each; anterior margins with 5 and 0 setae respectively; coxal plate VII trapezoid, with concave ventral margin; posterior lobe with 1 seta; coxal gills II-VI ovoid, ratio of gills/bases of pereopod are 1.1/1, 1.1/1, $1 / 1,0.9 / 1,0.7 / 1$, respectively.

ANTENNA I (Fig. 14A): slender, about $0.5-0.55$ of body length; peduncular articles moderately slender, ratio is $1 / 0.84 / 0.40$; flagel- 




Fig. 14. Niphargus valachicus Dobreanu et Manolache, 1933, O': A — antenna I; B — accessory flagellum of antenna I; C - antenna II; D — gnathopod I; E — gnathopod II; F — distoventral corner of palmar margin of chela of GnII.

Рис. 14. Niphargus valachicus Dobreanu et Manolache, 1933, О': А — антенна I; В - дополнительный жгутик антенны I; C — антенна II; D — гнатопод I; Е — гнатопод II; F — дистовентральный угол клешни GnII. 


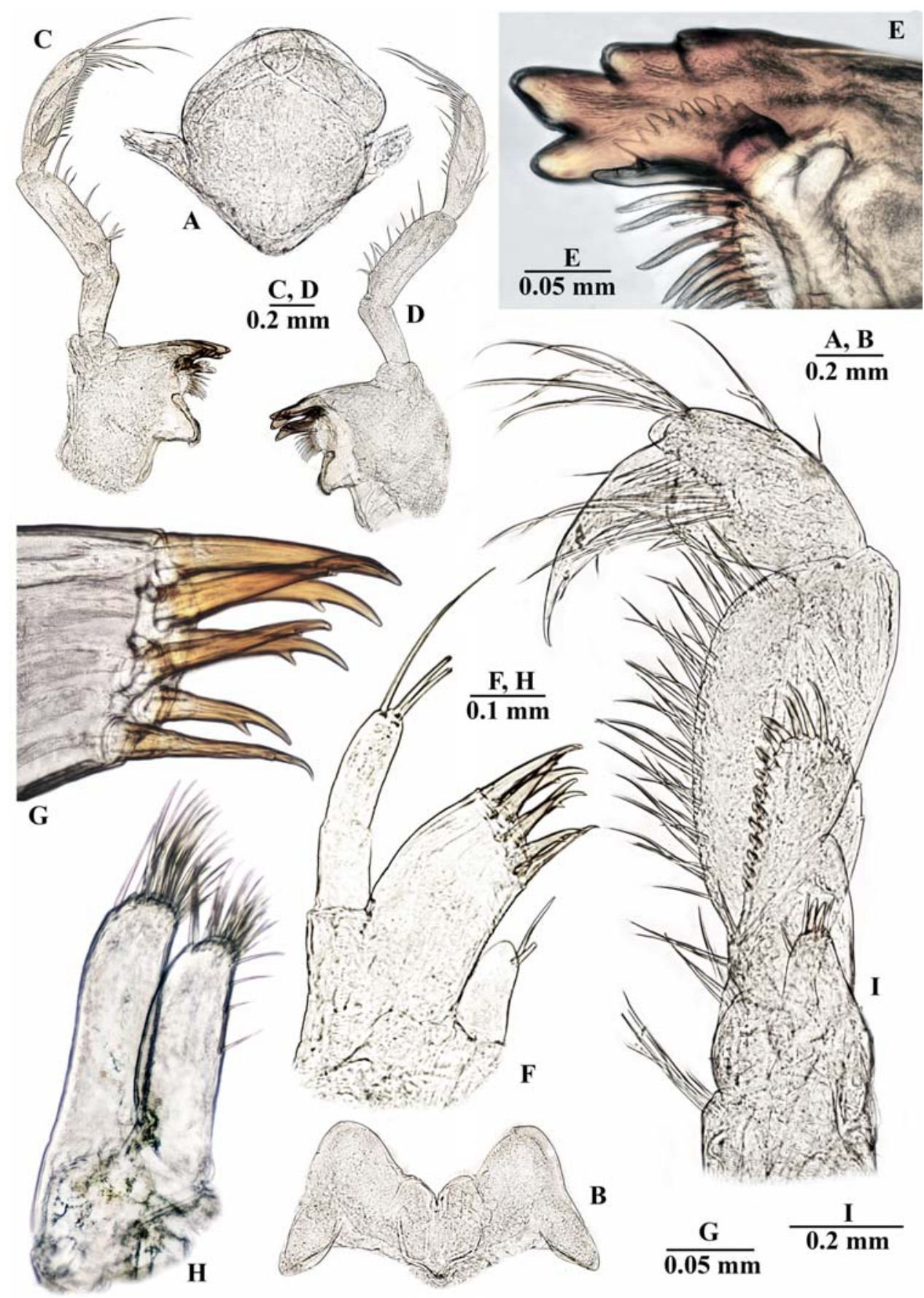

Fig. 15. Niphargus valachicus Dobreanu et Manolache, 1933, O': A - upper lip; B - lower lip; C, D mandible; $\mathrm{E}$ - incisor process and pars incisiva of mandible; F — maxilla I; G - same, distal margin of outer lobe; $\mathrm{H}$ - maxilla II; I - maxilliped.

Pис. 15. Niphargus valachicus Dobreanu et Manolache, 1933, О’: А — верхняя губа; В - нижняя губа; C, D — мандибула; E — режущий отросток и pars incisiva мандибулы; F — максилла I; G — то же, дистальный край наружной доли; Н — максилла II; I — максиллипед. 


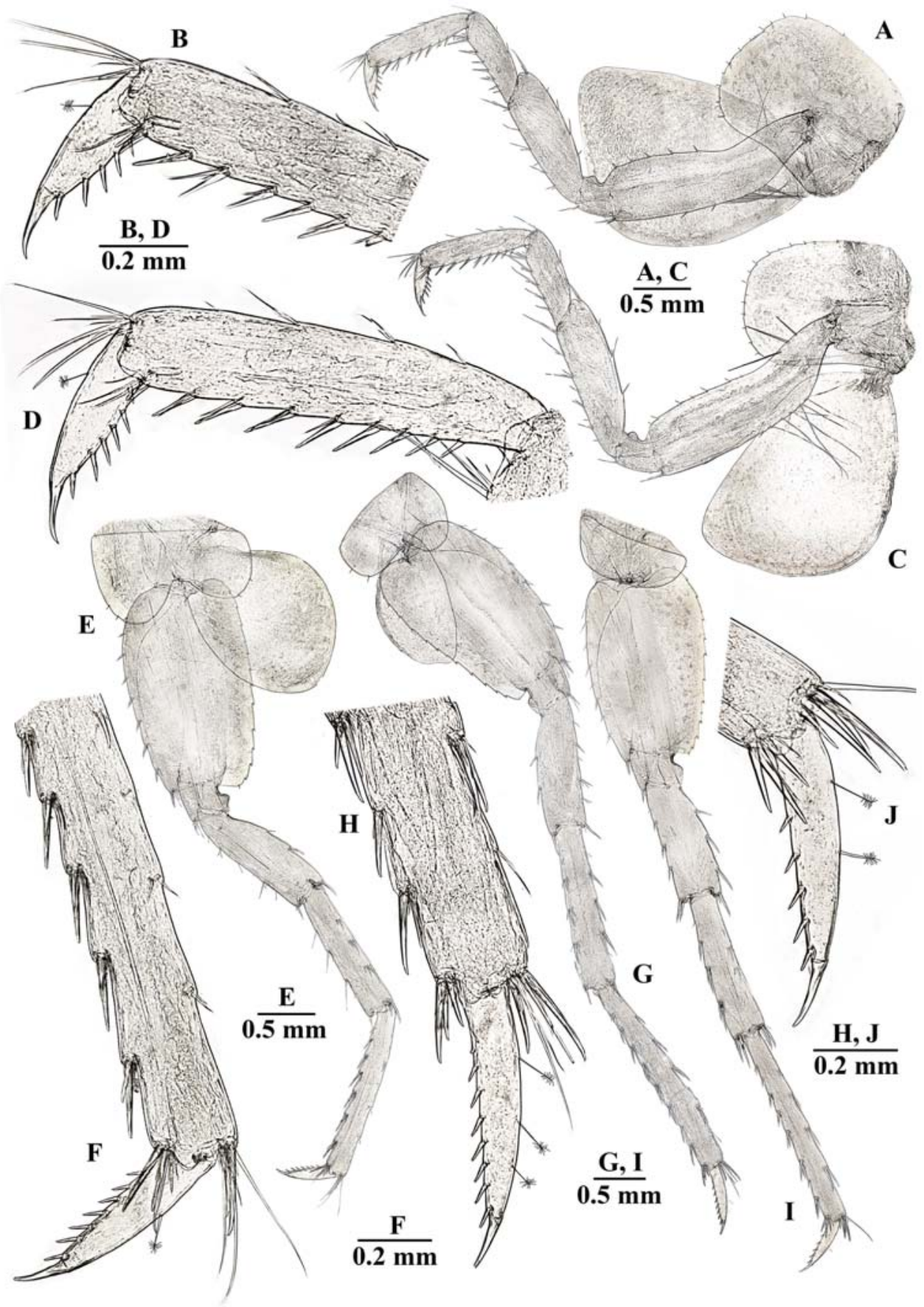

Fig. 16. Niphargus valachicus Dobreanu et Manolache, 1933, O': A — pereopod III; B - dactylus of PIII; $\mathrm{C}$ - pereopod IV; D - dactylus of PIV; E - pereopod V; F - dactylus of PV; G - pereopod VI; H dactylus of PVI; I - pereopod VII; J - dactylus of PVII.

Pис. 16. Niphargus valachicus Dobreanu et Manolache, 1933, О': А — переопод III; В - дактилус PIII; C — переопод IV; D — дактилус PIV; E — переопод V; F — дактилус PV; G — переопод VI; H дактилус PVI; I — переопод VII; J — дактилус VII. 


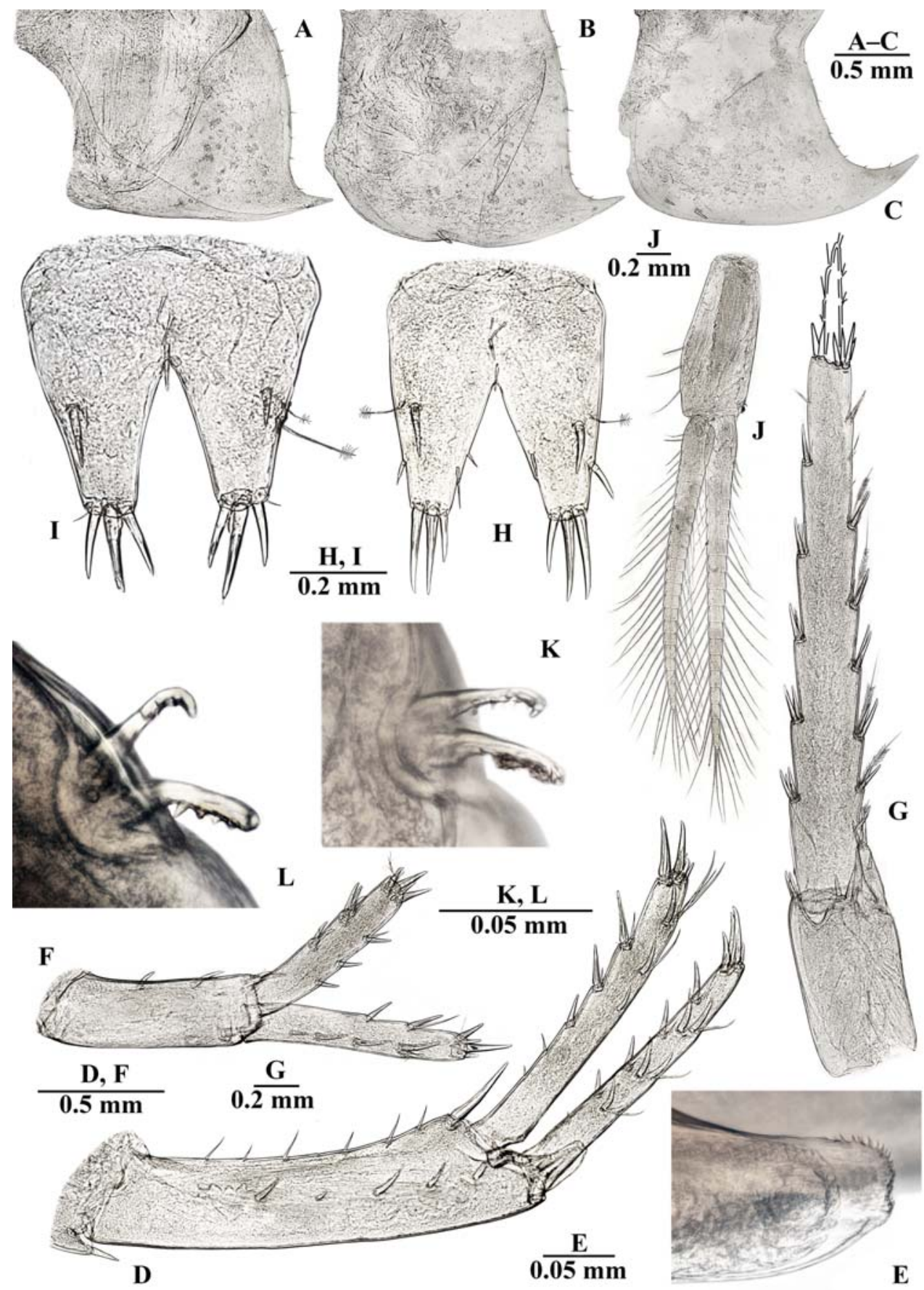

Fig. 17. Niphargus valachicus Dobreanu et Manolache, 1933, O': A-C — epimeral plates I-III; D — uropod I; E — same, spoon-shaped process of uropod I; F — uropod II; G — uropod III; H, I — telson; J — pleopod III; K, L - retinacle of pleopod III.

Pис. 17. Niphargus valachicus Dobreanu et Manolache, 1933, О': А-C - эпимеральные пластины I-III; $\mathrm{D}$ - уропод I; E — то же, ложкообразный придаток уропод I; F — уропод II; G - уропод III; H, I тельсон; J — плеопод III; K, L — ретинакула плеопод III. 
lum consisting of 31 articles, most of them with 2 short aesthetascs each; accessory flagellum short, 2-articulated (Fig. 14B); ratio of antennas $\mathrm{I} / \mathrm{II}$ is $1 / 0.7$.

ANTENNA II (Fig. 14C): peduncular articles moderately stout, with several long setae along ventral and dorsal margins, dorsal setae slightly shorter than inner ones; flagellum relatively short, consisting of 11 articles with relatively short setae; lengths of peduncle articles 4 / 5 is $1 / 0.94$; flagellum is 0.95 of the length of peduncular articles $4+5$.

LABRUM (upper lip) (Fig. 15A): entire, subrounded, with fine hair distally.

LABIUM (lower lip) (Fig. 15B): with entire, subrounded, wide apart, parallel outer lobes and well developed smaller inner lobes.

MANDIBLE (Fig. 15C-E). Left mandible: incisor with 5 teeth, lacinia mobilis with 4 teeth; with a row of 8 few spatulate setae and one long seta at base of molar (Fig. 15D); ratio of mandibular palp article $2 / 3$ (distal) is $1 / 1.1$; proximal article of palp without setae; article II with 9-11 setae; distal article with a group of 6 A-setae; 2 3 groups of B-setae; 27 D-setae and 5 E-setae. Right mandible: incisor process with 4 teeth, lacinia mobilis toothed, with 8-9 dorsal teeth and with a row of 9-10 raker setae (Fig. 15E).

MAXILLA I (Fig. 15F, G): inner lobe with 2 distal setae, outer lobe with 7 robust spines ( 6 spines with 1 strong lateral tooth each, inner spine with 2-3 small lateral teeth (1-1-1-1-11-3) (Fig. 15G)); palp 2-articulated, distal article with 3 simple setae distally.

MAXILLA II (Fig. 15H): both plates with numerous long distal simple setae, inner lobe with row of fine setae along inner margin.

MAXILLIPED (Fig. 15I): inner plate short, with 3 distal robust setae intermixed with 5 distal simple setae; outer plate reaching half of palpal article 2 and bearing a row of 18 distolateral spines and distal setae; palpal article 3 with 2 median and 1 distal bunches of setae at outer margin; palpal article 4 with 1 median seta at inner and outer margin; nail shorter than pedestal, with 1 seta near basis.

GNATHOPOD I (Fig. 14D): ischium with a group of 7-9 posterodistal setae; carpus is 0.35 of length of basis and 0.50 of length of propodus, with a single distal group of setae anteriorly, with transverse rows of setae along posterior margin and a row of setae posterolaterally; propodus subtrapezoidal, setose, with $8-9$ rows of setae at posterior margin, anterior margin with 2 groups of total 4-7 setae each in addition to anterodistal group of 6-7 setae, several groups of short setae on inner surface, palmar corner armed with 1 long spiniform palmar seta, 5 serrated spiniform setae, single supporting spiniform seta on inner surface; dactylus with 8 setae along anterior margin, with row of short setae along inner margin; length of nail is 0.2 of total length of dactylus.

GNATHOPOD II (Fig. 14E, F): ratio of length/width of basis is $0.3 / 1$, with $2-3$ dorsolateral setae; ischium with 3 posterodistal setae; carpus is 0.41 of length of basis and $0.69-0.70$ of length of propodus, with distal group of setae anteriorly, with row of seta along posterior margin and a row of seta posterolaterally; propodus subtrapezoidal, setose, almost equal to propodus of $\mathrm{GnI}(\mathrm{GnI} / \mathrm{II}$ as $0.96 / 1)$, posterior margin with $10-11$ rows of setae, anterior margin with $1-2$ setae in addition to 8-10 anterodistal setae, with several groups of setae on inner surface, palmar corner with 1 strong palmar spiniform seta, single supporting spiniform seta on inner surface and 5 denticulated thick spiniform setae on outer side (Fig. 14F); dactylus with 7 setae along anterior margin and few short setae along inner margin; the length of nail is about 0.18 of total length of dactylus.

PEREOPODS III-IV (Fig. 16A, C) almost similar in size and shape.

PEREOPOD III (Fig. 16A): basis is 3.6-3.7 times as long as wide, with posterior margin bearing long marginal setae, with distoventral group of setae; ischium short, rectangular, with distoventral group of setae; merus with slender simple setae along dorsal and ventral margins; ratio of carpus/propodus is 0.8 ; propodus with 8 groups of spines along ventral margin; dactylus relatively stout, slightly curved, sharp distally, with 5 additional ventral spines and 1 median short plumose seta at outer margin (Fig. 16B); length of nail is 0.34 of total length of dactylus; ratio of dactyli of PpIII/IV is $1 / 1.1$. 
PEREOPOD IV (Fig. 16C): basis is 3.5 times as long as wide, with posterior margin bearing long marginal setae, with distoventral group of setae; ischium short, rectangular, with distoventral group of setae; merus with slender simple setae along dorsal and ventral margins; ratio of carpus/propodus is 0.80 ; propodus with 8 groups of spines along ventral margin; dactylus relatively stout, slightly curved, sharp distally, with 5 additional ventral spines and 1 median short plumose seta at outer margin (Fig. 16D); length of nail is 0.34 of total length of dactylus.

PEREOPODS V-VII (Fig. 16E, G, I): the lengths of $\mathrm{PpV} / \mathrm{VI} / \mathrm{VII}$ is 1/1.12/1.04.

PEREOPOD V (Fig. 16E, F): ratio of length/ width of basis is $1 / 0.61$, almost rectangular, with distinct posteroventral lobe; posterior margin straight or slightly convex, with a row of 16 slender marginal setae; anterior margin convex, with a row of 8 slender marginal setae, which distinctly longer than posterior ones, and a group of setae in distal part; ischium subquadrate; merus with 5-6 bunches of slender spines along dorsal margin and with 2 spines on ventral margin; propodus slender, 7.9-8.0 times as long as wide, with several bunches of short spines; dactylus (Fig. 16F) with 7 small additional ventral spines and 1 median short plumose seta at outer margin.

PEREOPOD VI (Fig. 16G, H): ratio of length/width of basis is $1 / 0.6$, with distinct posteroventral lobe and slightly concave or straight posterior margin, bearing a row of 15 short marginal setae; anterior margin convex, with a row of 8 groups of marginal setae; merus with several bunches of short spines along dorsal and ventral margins; carpus with a group of spines intermixed with single short setae; propodus slender, about 8 times as long as wide, with several group of short spines; dactylus (Fig. $16 \mathrm{H})$ slender, with 8 additional ventral spine and 3 short median plumose setae at outer margin.

PEREOPOD VII(Fig. 16I, J): ratio of length/ width of basis is $1 / 0.65$, with posteroventral lobe and slightly convex posterior margin bearing a row of 13 short marginal setae; anterior margin convex, with a row of 8 longer marginal setae; carpus with 4 groups of short spines along dorsal and 3 along ventral margins; propodus slender, about 7.9-8.0 times as long as wide, with several groups of short spines; dactylus (Fig. 16J) with 5 spines at inner margin and 2 short median plumose setae at outer margin.

PLEOPODS (Fig. 17J): pleopod I and II with basal segment without setae, with 2 hooks in retinacle; pleopod III with basal segment armed 3 medium sized lateral plumose setae, 23 medium size simple setae at surface and 2 coupling hooks in retinacle (Fig. 17L, K).

UROPOD I (Fig. 17D). Male: protopodite longer than rami, 4.0 times as long as wide, with dorsointernal row of 5 spiniform setae and 2 subdistal spines, dorsoexternal row of 7 slender and one robust spines and characteristic spoonshaped appendage distally (Fig. 17E); rami straight, almost subequal in length, endopodite not paddle-like, with 5 dorsolateral and 3 mesial spines accompanying several setae, 5 apical spines; exopodite with 4 dorsal spines and 3 dorsomesial groups consisting of 2 spines and 1-2 setae each at outer surface, 5 apical spines.

UROPOD II (Fig. 17F): protopodite 3 times as long as wide, almost subequal rami; rami with lateral, mesial and distal slender spines, endopodite with 2 groups of spines dorsolaterally and 3 spines ventrolaterally, 5 spines apically; exopodite with 2 spines dorsolaterally, 4 spines mesially and 5 apically.

UROPOD III (Fig. 17G): similar in females and males; protopodite 1.8 times as long as wide, without lateral and with 6-7 apical spiniform setae; rami unequal, endopodite short, about 8.8-9.0 times shorter than exopodite, with one lateral seta and 2 spiniform setae apically; distal article is 0.22 of length of proximal article, with 2-3 groups of thin-flexible setae along each margin and group of simple setae apically; proximal article with 5-6 groups of thin-flexible, plumose and spiniform setae along inner and outer margins.

TELSON (Fig. 17I, H): ratio of length/width is $1 / 0.86$ in males and $1 / 1.06$ in females; cleft is $0.52-0.58$ of length of telson; margins straight, narrowing apically; with variable armature, including 3 medium size distal spines on each 
lobe, one dorsal spine and one slender lateral spine, accompanying by 2 plumose setae on each outer margins; sometimes there are single slender spines on inner surface (Fig. 17H); dorsal surface with 3-4 small mesial setae; apical spiniform setae are $0.32-0.34$ of length of telson.

BODY SIZE. The largest collected male has tbl. $14.0 \mathrm{~mm}$.

COLORATION. Body, appendages and internal organs are grey- or yellowish, similar to the coloration of representatives of the genus Gammarus. Bright yellow eyespots are clearly visible on the head both in males and in females.

GENBANK ACCESSION NUMBERS. MW679712.

TAXONOMIC REMARKS. Niphargus valachicus can be easily identified by: 1) shapes of GnI-II, which have the width significantly less than the depth (Fig. 14D, E), 2) significantly produced posteroventral margins of epimeral plates I-III (Fig. 17A-C) and 3) the presence of 5-7 additional spines of dactyli of PpIII-VII (Fig. 16). Niphargus mediodanubialis Dudich, 1941 is suggested as a junior synonym of this species (Copilaş-Ciocianu et al., 2017).

ECOLOGY. Specimens of N. valachicus were found in a small, shallow pond with aquatic vegetation, where large predators (e.g., fishes) were apparently absent. Another malacostracan species found there was Synurella sp. (Amphipoda, Crangonyctidae).

DISTRIBUTION. The species was firstly recorded from the southwestern Georgia and the Kolkhida lowland valley of the Eastern Black Sea (Colchis), as well as from the southwestern Caucasus. Previously, it was recorded from the floodplains and lowlands of the Danube River in south-eastern Germany, Croatia, Hungary, Serbia, reaching the lowlands of the Black Sea in Bulgaria, Romania, Ukraine and Turkey, and even to the shores of the Caspian Sea in Iran (Dedju, 1980; Sket, 1981; Karaman, 1998; Akbulut et al., 2001; Fišer et al., 2009b; Copilaş-Ciocianu et al., 2014, 2017, 2018). At the same time, some records outside the Europe need to be clarified through molecular genetic analysis.

\section{Niphargus magnus Birštein, 1940}

Figs 18-22.

Niphargus longicaudatus magnus Birštein, 1940: 4748, fig. 1.

MATERIAL EXAMINED. NEOTYPE, $\sigma^{7}$ (bl. $15 \mathrm{~mm}$ ), ZMMU Mb-1174, Ochamchira District, a spring near entrance to the Golova Otapa cave, $42^{\circ} 55.321^{\prime} \mathrm{N}, 41^{\circ} 32.327^{\prime} \mathrm{E}$, about $244 \mathrm{~m}$ above sea level, hand net sampling, coll. D. Palatov, 4 February 2018.

Other material: + (bl. $10 \mathrm{~mm}$ ), ZMMU Mb1175, Abkhazia, Ochamchira District, same locality, collectors and data as neotype; $6 \sigma^{7} \sigma^{7}$, 15 90 , Abkhazia, Ochamchira District, same locality, collectors and data as neotype.

\section{DESCRIPTION.}

BODY: yellowish, moderately slender.

HEAD: without rostrum, with yellow pigmented spots close to anterior lobe and with subrounded lateral cephalic lobes and excavated anteroventral sinus.

PEREON: pereonites I-VII without setae, smooth.

PLEOSOMA: pleonites I-III with several short marginal setae on each posterodorsal margin.

EPIMERAL PLATES (Fig. 21A-C): posteroventral corners of epimeral plates I-III with sharp posteroventral corners. Epimeral plate I: ventral margin convex, posterior margin almost straight; without spines along ventral margin; with 8 setae along posterior margin; posteroventral angle tapered into a small spike. Epimeral plate II: posterior margin almost straight, ventral margin distinctly convex; with a spiniform seta on ventral margin; 7 setae along posterior margin; posteroventral angle tapered into a spike. Epimeral plate III: posterior margin oblique, ventral margin slightly convex or almost straight; with 3 spiniform setae on ventral margin; with 9 setae along posterior margin; posteroventral angle tapered into a spike.

UROSOMITES: urosomite I with 1 slender spine accompanying 1-2 simple seta on each side dorsolaterally, with 1 posteroventral spines near basis of uropod I; urosomite II with 3 slender spines accompanying few simple seta 

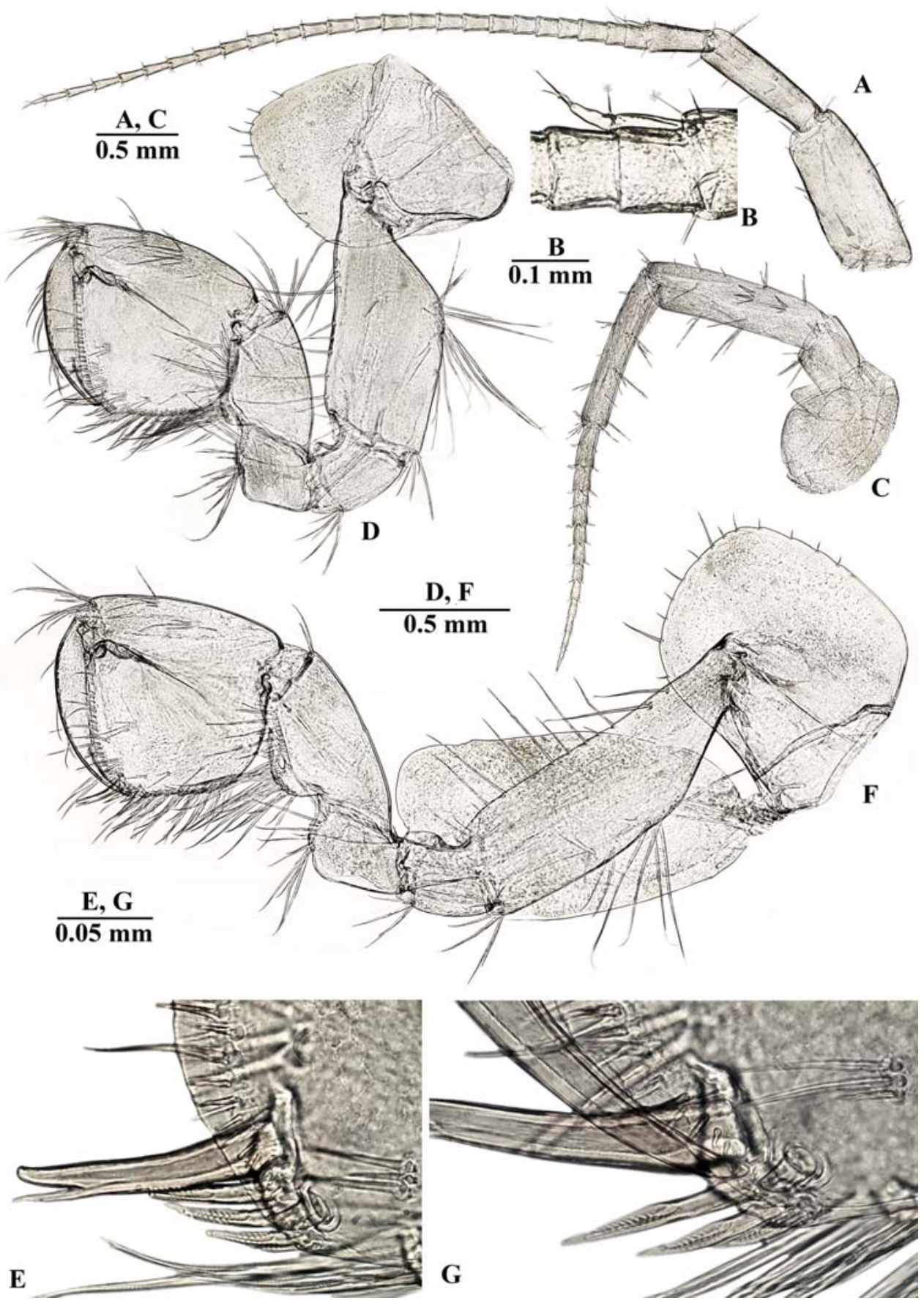

Fig. 18. Niphargus magnus Birštein, 1940, $\mathrm{O}^{7}$ : A — antenna I; B - accessory flagellum of antenna I; C antenna II; D - gnathopod I; E - distoventral corner of palmar margin of chela of GnII; F - gnathopod II; G - distoventral corner of palmar margin of chela of GnII.

Pис. 18. Niphargus magnus Birštein, 1940, О': А — антенна I; В - дополнительный жгутик антенны I; C — антенна II; D — гнатопод I; E — дистовентральный угол клешни GnII; F — гнатопод II; G дистовентральный угол клешни GnII. 




Fig. 19. Niphargus magnus Birštein, 1940, O: A - upper lip; B - lower lip; C, E - mandible; D, F incisor process and pars incisiva of mandible; $\mathrm{G}$ - maxilla I; H - same, distal margin of outer lobe; I maxilla II; J - maxilliped.

Рис. 19. Niphargus magnus Birštein, 1940, О7: А — верхняя губа; В — нижняя губа; С, Е — мандибула; $\mathrm{D}, \mathrm{F}$ - режущий отросток и pars incisiva мандибулы; G — максилла I; H — то же, дистальный край внешний лопасти; I - максилла II; J - максиллипед. 

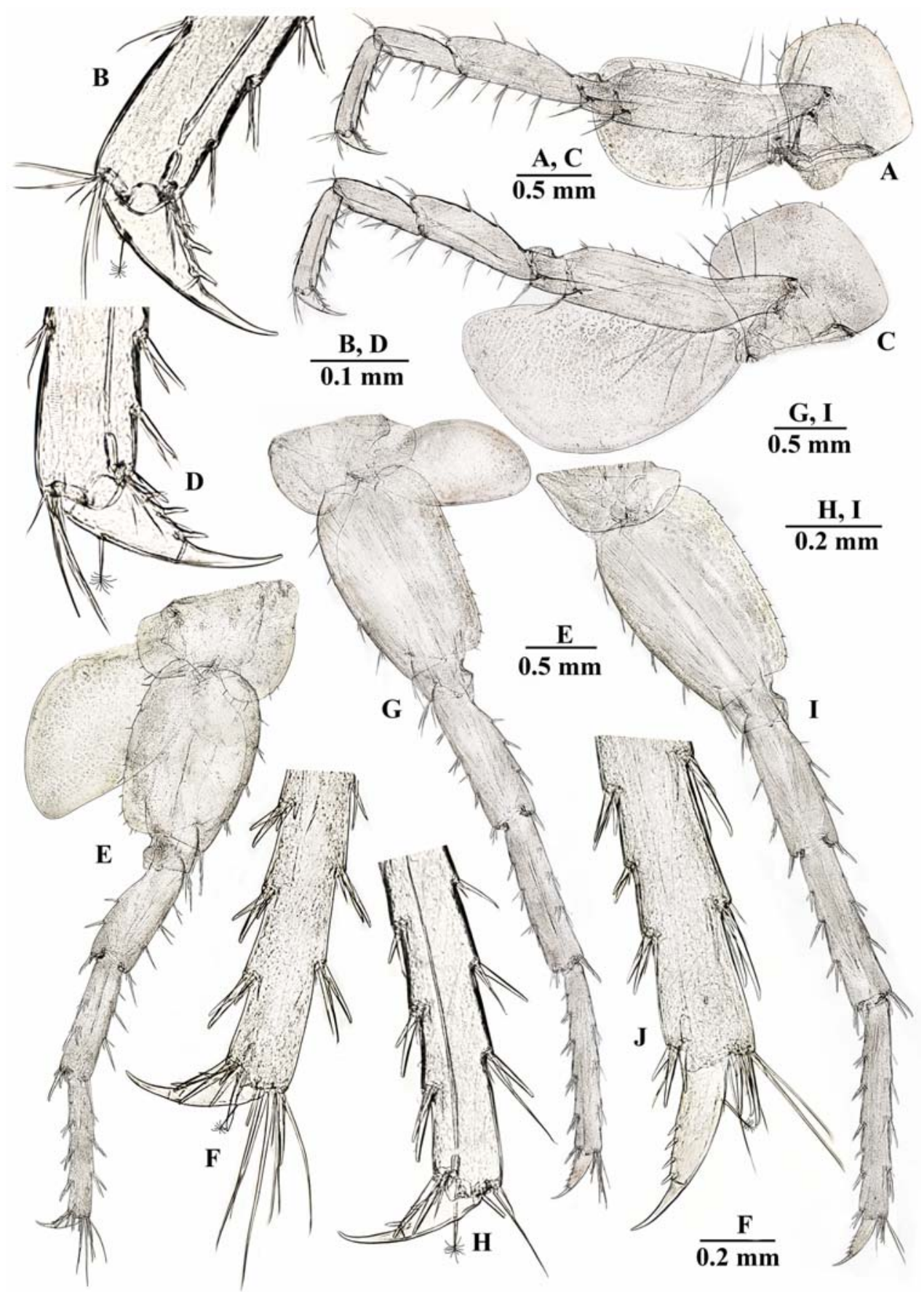

Fig. 20. Niphargus magnus Birštein, 1940, O': A — pereopod III; B — dactylus of PIII; C — pereopod IV; D - dactylus of PIV; E - pereopod V; F - dactylus of PV; G - pereopod VI; H - dactylus of PVI; I pereopod VII; J - dactylus of PVII.

Рис. 20. Niphargus magnus Birštein, 1940, Оج: А — переопод III; В - дактилус РIII; C — переопод IV; D — дактилус PIV; E - переопод V; F — дактилус PV; G — переопод VI; H - дактилус PVI; I переопод VII; J - дактилус PVII. 


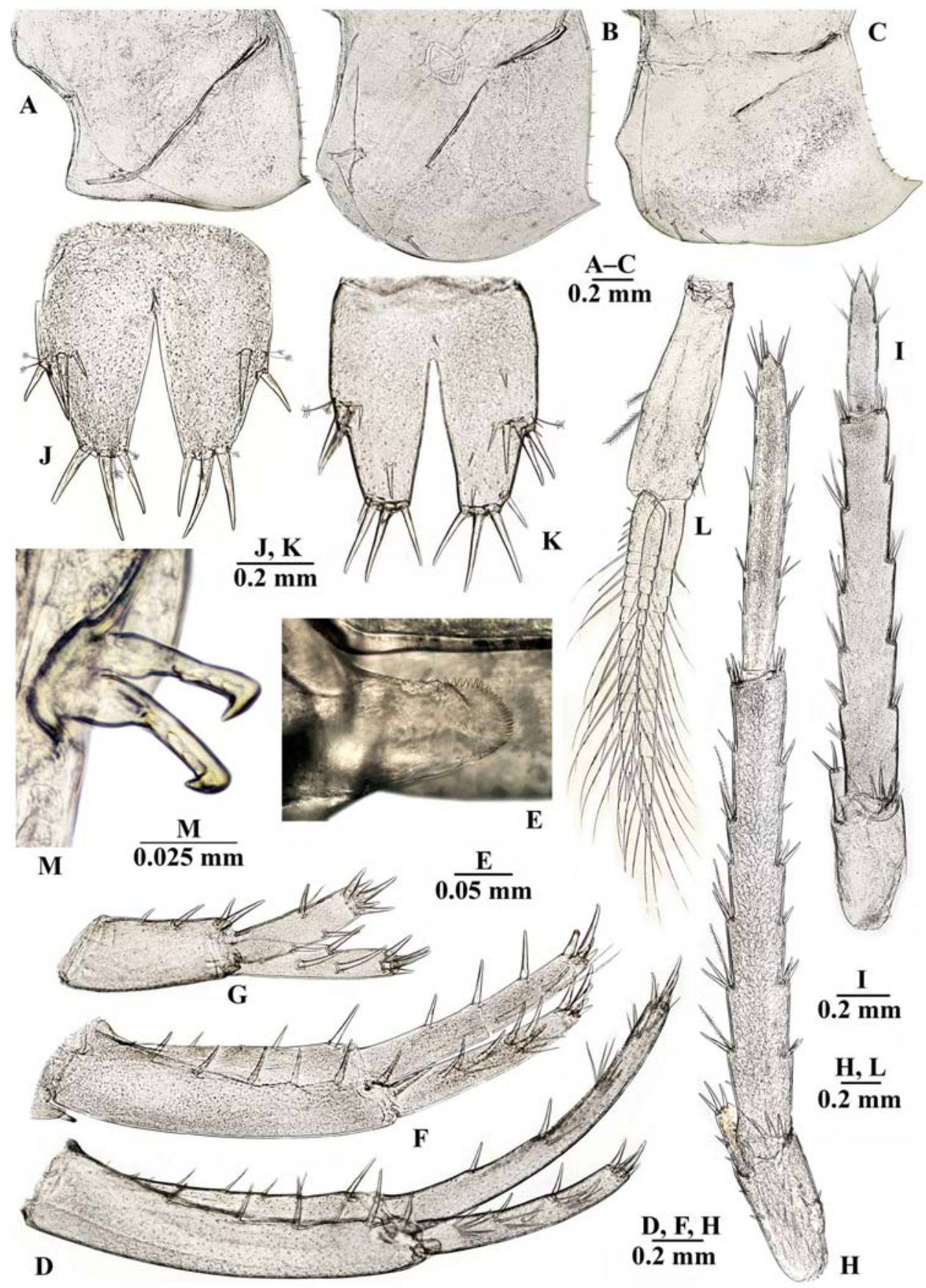

Fig. 21. Niphargus magnus Birštein, 1940, O' (A-E, G, H, J, L, M) and $\odot$ (F, I, K): A-C - epimeral plates I-III; D, F — uropod I; E — same, spoon-shaped appendage of uropod I; G — uropod II; H, I — uropod III; J, K - telson; L - pleopod III; M - retinacle of pleopod III.

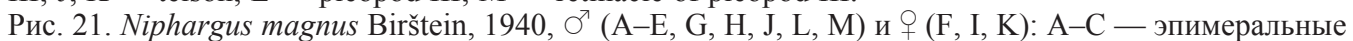
пластины I-III; D, F - уропод I; E — то же, ложкообразный придаток уропод I; G - уропод II; H, I — уропод III; J, K — тельсон; L — плеопод III; M — ретинакула плеопод III. 
on each side dorsolaterally, urosomite III unarmed.

COXAE (Figs 18D, F; 20A, C, E, G, I): ratio of width/depth of coxal plates I-IV are $1 / 1,1$ / $0.85,1 / 0.95$ and $1 / 1$, respectively; coxal plate I subquadrate, with rounded anteroventral corner, armed with 11 marginal and 1 submarginal setae, anterior margin of coxal plate II with 12 13 marginal setae; anterior margins of coxal plates III and IV with rounded anteroventral corners and 10 marginal setae each; coxal plates $\mathrm{V}-\mathrm{VI}$ with large lobes anteriorly, posterior margins with 4-5 and 2 setae, respectively; anterior margins with 6 and 0 setae respectively; coxal plate VII trapezoid, with concave ventral margin; posterior lobe with 1 seta; coxal gills II-VI ovoid, ratio of gills/bases of pereopod are $1 / 1,0.9 / 1,1.2 / 1,1 / 2-1.3 / 1,0.8 / 1$, respectively.

ANTENNA I (Fig. 18A): slender, about $0.48-0.5$ of body length; peduncular articles moderately slender, ratio is $1 / 0.84 / 0.41$; flagellum consisting of 25 articles, most of them with 2 short aesthetascs each; accessory flagellum short, 2-articulated (Fig. 18B); ratio of antennas $\mathrm{I} / \mathrm{II}$ is $1 / 0.82$.

ANTENNA II (Fig. 18C): peduncular articles moderately stout, with several long setae along ventral and dorsal margins, dorsal setae slightly shorter than inner ones; flagellum relatively short, consisting of 13 articles with relatively short setae; lengths of peduncle articles 4/ 5 is $1 / 0.89$; flagellum is 0.71 of the length of peduncular articles $4+5$.

LABRUM (upper lip) (Fig. 19A): entire, subrounded, with fine hair distally.

LABIUM (lower lip) (Fig. 19B): with entire, subrounded outer lobes slightly tilted on each other and well developed smaller inner lobes.

MANDIBLE (Fig. 19C-F). Left mandible: incisor with 5 teeth, lacinia mobilis with 4 teeth; with a row of 9 raker setae, few spatulate setae and one long seta at base of molar (Fig. 20D); ratio of mandibular palp article $2 / 3$ (distal) is $1 /$ 1-1.1; proximal article of palp without setae; article II with 12-13 setae; distal article with a group of 9 A-setae; 3-4 groups of B-setae; 23$25 \mathrm{D}$-setae and 6 E-setae. Right mandible: inci- sor process with 4 teeth, lacinia mobilis toothed, with 8 dorsal and 3-4 ventral teeth and with a row of 8 raker setae (Fig. 20F).

MAXILLA I (Fig. 19G, H): inner lobe with a distal seta, outer lobe with 7 robust spines (6 spines with 1 strong lateral tooth each, inner spine with 3 small lateral teeth (1-1-1-1-1-13) (Fig. 19H)); palp 2-articulated, distal article with 5-6 simple setae distally.

MAXILLA II (Fig. 19I): both plates with numerous long distal simple setae, inner lobe with row of fine setae along inner margin.

MAXILLIPED (Fig. 19J): inner plate short, with 3 distal robust setae intermixed with 6 distal simple setae; outer plate reaching half of palpal article 2 and bearing a row of 18 distolateral spines and distal setae; palpal article 3 with 2 median and 1 distal bunches of setae at outer margin; palpal article 4 with 1 median seta at outer margin; nail shorter than pedestal, with 1 seta near basis.

GNATHOPOD I (Fig. 18D): ischium with a group of 7-9 posterodistal setae; carpus is 0.45 of length of basis and 0.63 of length of propodus, with a single distal group of setae anteriorly, with transverse rows of setae along posterior margin and a row of setae posterolaterally; propodus subtrapezoidal, setose, with 8 rows of setae at posterior margin, anterior margin with 2 groups of total 5-7 setae each in addition to anterodistal group of 8-10 setae, several groups of short setae on inner surface, palmar corner armed with 1 long spiniform palmar seta, 4 serrated spiniform setae, single supporting spiniform seta on inner surface (Fig. 18E); dactylus with 9 setae along anterior margin, with row of short setae along inner margin; length of nail is 0.36 of total length of dactylus.

GNATHOPOD II (Fig. 18F): ratio of length/ width of basis is $0.34 / 1$, with $10-12$ dorsolateral setae; ischium with 6 posterodistal setae; carpus is 0.48 of length of basis and 0.78 of length of propodus, with distal group of setae anteriorly, with row of seta along posterior margin and a row of seta posterolaterally; propodus subtrapezoidal, setose, larger than propodus of $\mathrm{GnI}$ ( $\mathrm{GnI} / \mathrm{II}$ as $0.74 / 1)$, posterior margin with $8-10$ rows of setae, anterior margin with 2 groups of 
setae, 4-5 setae each, in addition to 8-10 anterodistal setae, with several groups of setae on inner surface, palmar corner with 1 strong palmar spiniform seta, single supporting spiniform seta on inner surface and 3 denticulated thick spiniform setae on outer side (Fig. 18G); dactylus with 7 setae along anterior margin and few short setae along inner margin; the length of nail is about 0.3 of total length of dactylus.

PEREOPODS III-IV (Fig. 20A, C) almost similar in size and shape.

PEREOPOD III (Fig. 20A): basis is 3.5-3.6 times as long as wide, with posterior margin bearing long marginal setae, with distoventral group of setae; ischium short, rectangular, with distoventral group of setae; merus with slender simple setae along dorsal and ventral margins; ratio of carpus/propodus is 0.8 ; propodus with 5 groups of spines along ventral margin; dactylus relatively stout, curved, sharp distally, with 3 additional ventral spines and 1 median short plumose seta at outer margin (Fig. 20B); length of nail is 0.45 of total length of dactylus; ratio of dactyli of PpIII/IV is $1 / 0.9$.

PEREOPOD IV (Fig. 16C): basis is 3.7 times as long as wide, with posterior margin bearing long marginal setae, with distoventral group of setae; ischium short, rectangular, with distoventral group of setae; merus with slender simple setae along dorsal and ventral margins; ratio of carpus/propodus is 0.87 ; propodus with 5 groups of spines along ventral margin; dactylus relatively stout, slightly curved, sharp distal$1 y$, with 3 additional ventral spines and 1 median short plumose seta at outer margin (Fig. 20D); length of nail is 0.47 of total length of dactylus.

PEREOPODS V-VII (Fig. 20E, G, I): the lengths of $\mathrm{PpV} / \mathrm{VI} / \mathrm{VII}$ is 1/1.52/1.52.

PEREOPOD V (Fig. 20E, F): ratio of length/ width of basis is $1 / 0.67$, almost rectangular, with distinct posteroventral lobe; posterior margin slightly convex, with a row of 13-14 slender marginal setae; anterior margin convex, with a row of 4-6 slender marginal setae, which distinctly longer than posterior ones, and a group of setae in distal part; ischium subquadrate; merus with 3 bunches of slender spines along dorsal margin and with 2 spines on ventral margin; propodus slender, 6.2 times as long as wide, with several bunches of short spines; dactylus (Fig. 20F) with 2 small additional ventral spines and 1 median short plumose seta at outer margin.

PEREOPOD VI (Fig. 20G, H): ratio of length/width of basis is $1 / 0.62$, with distinct posteroventral lobe and slightly concave or straight posterior margin, bearing a row of 15 short marginal setae; anterior margin convex, with a row of 5 groups of marginal setae; merus with several bunches of short spines along dorsal and ventral margins; carpus with a group of spines intermixed with single short setae; propodus slender, about 6.7 times as long as wide, with several group of short spines; dactylus (Fig. 20H) slender, with 4 additional ventral spine and a short median plumose seta at outer margin.

PEREOPOD VII (Fig. 20I, J): ratio of length/ width of basis is $1 / 0.62$, with posteroventral lobe and slightly convex posterior margin bearing a row of 16 short marginal setae; anterior margin convex, with a row of 6 groups of longer marginal setae; carpus with 3 groups of short spines along dorsal and ventral margins; propodus slender, about 6.9-7.0 times as long as wide, with several groups of short spines; dactylus (Fig. 20J) with 4 spines at inner margin and a short median plumose seta at outer margin.

PLEOPODS (Fig. 21L): pleopod I and II with basal segment without setae or with a medium size simple setae at surface, with 2 hooks in retinacle; pleopod III with basal segment armed 3 medium sized lateral plumose setae, 2-3 medium size simple setae at surface and 2 coupling hooks in retinacle (Fig. 21M).

UROPOD I (Fig. 21F, D): slightly different in males and females.

Male (Fig. 21D): protopodite longer than rami, 4.7 times as long as wide, with dorsointernal row of 6 spiniform setae and 2 subdistal spines, dorsoexternal row of 5 slender and one robust spines and characteristic spoon-shaped appendage distally (Fig. 21E); rami curved, ratio of endopodite/exopodite is 1/0.61 in lenght; endopodite not paddle-like, with 3 dorsolateral and 3 mesial spines accompanying several 
setae, 5 apical spines; exopodite with 3 mesial spines at inner surfase and 3 dorsomesial groups consisting of 1-2 spines and 5-6 setae each at outer surface, 5 apical spines. Female (Fig. 21F): protopodite longer than rami, 3.7 times as long as wide, with dorsointernal row of 5 spiniform setae and 2 subdistal spines, dorsoexternal row of 3 slender and one robust spines, without spoon-shaped appendage; rami straight ratio of endopodite/exopodite is $1 / 0.84$ in lenght; endopodite not paddle-like, with 3 dorsolateral and 2 groups of mesial spines accompanying several setae at inner surface, 5 apical spines; exopodite with 3 mesial spines at inner surfase and 2 dorsomesial groups consisting of 1-2 spines and 3-4 setae each at outer surface, 5 apical spines.

UROPOD II (Fig. 21G): protopodite 2.5 times as long as wide, almost subequal rami; rami with lateral, mesial and distal slender spines, endopodite with a spine dorsolaterally and 2 spines ventrolaterally, 5 spines apically; exopodite with a spine dorsolaterally, 2 spines mesially and 5 apically.

UROPOD III (Fig. 21H, I): different in males and females. Male (Fig. 21H): protopodite 2.2 times as long as wide, with $2-3$ groups of small lateral spines and with 5-6 apical spiniform setae; rami unequal, endopodite short, about 11 times shorter than exopodite, with 1-2 lateral setae and 3 spiniform setae apically; distal article is 0.67 of length of proximal article, with 4-5 groups of thin-flexible setae along each margin and group of simple setae apically; proximal article with 6-7 groups of thin-flexible, plumose and spiniform setae along inner and outer margins. Female (Fig. 21I): protopodite 1.9-2.0 times as long as wide, with 2 small lateral spines and with 5-6 apical spiniform setae; rami unequal, endopodite short, about 9 times shorter than exopodite, with 2 spiniform setae apically, without lateral setae; distal article is 0.37 of length of proximal article, with 2 groups of thin-flexible setae along each margin and group of simple setae apically; proximal article with 5 groups of thin-flexible, plumose and spiniform setae along inner and outer margins.
TELSON (Fig. 21J, K): ratio of length/ width is $1 / 0.90-0.97$; cleft is $0.58-0.65$ of length of telson; margins straight or weakly rounded, narrowing apically; with variable armature, including 3-4 medium size distal spines on each lobe, one group dorsal spines, including 1-3 spines (sometimes accompanied by single spikes) and one lateral spine, accompanying by 2 plumose setae on each outer margins; dorsal surface with 1-3 small mesial setae; apical spiniform setae are $0.34-0.38$ of length of telson.

BODY SIZE. One of the largest Caucasian species of the genus Niphargus. Females are mostly subequal in size to males; the largest collected female has tbl. $18.0 \mathrm{~mm}$; the largest collected male has tbl. $16.0 \mathrm{~mm}$.

COLORATION. Body, appendages and internal organs are yellowish (Figs 22A; 23), characteristic to epigean representatives of the genus Niphargus. Bright yellow eyespots are visible on the head in males and females (Fig. 23A, B). Gonads of females and eggs are purple.

GENBANK ACCESSION NUMBERS. MW679713, MW679714.

TAXONOMIC REMARKS. The species was originally described as $N$. longicaudatus magnus with morphological affinity to Niphargus longicaudatus karamani Schellenberg, 1935. In the original description, the distinctive features of the species were: 1) telson splitting for only $2 / 3$ of its length, 2) unequal elongated rami of uropods I in males, and 3) elongated outer ramus of uropod III in males (see Birštein, 1940, 1952). From other epigean Caucasian species, N. magnus can be distinguished by: 1) relatively slender pigmented body (Figs 22A; $23)$; 2) less produced posteroventral margins of epimeral plates I-III (Fig. 21A-C); 3) the presence of 1 spine on each posterodorsal margins of urosomite I and 3 spines on urosomite II; 4) unequal rami of uropod I in males (Fig. 21D); 5) dissimilar uropod III in males and females (Fig. 21H, I), with elongated outer rami in males (Fig. 21H).

Sidorov (2014) concluded that N. magnus is a senior synonym of $N$. iniochus Birštein, 1941, considering the structure of epimeral plates I- 

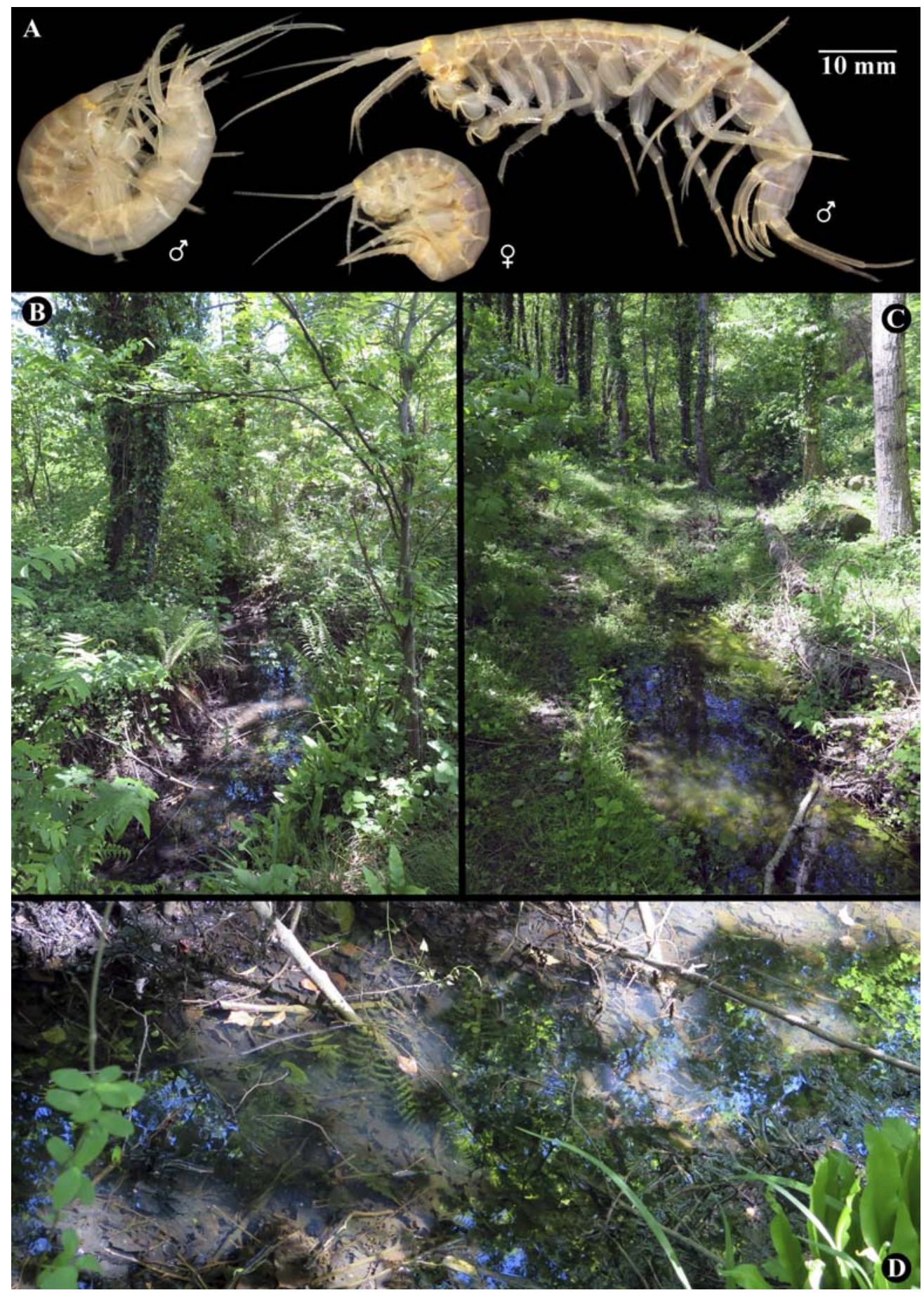

Fig. 22. Live coloration (A) and characteristic biotopes (B-D) of Niphargus cf. magnus Birštein, 1940 in the Tsuskhvadz River, Krasnodar Krai, Lazarevsky City District, south-western Caucasus.

Рис. 22. Прижизненная окраска (А) и характерные биотопы (B-D) Niphargus cf. magnus Birštein, 1940 на реке Цусхвадж, Краснодарский край, Лазаревский район, юго-западный Кавказ. 


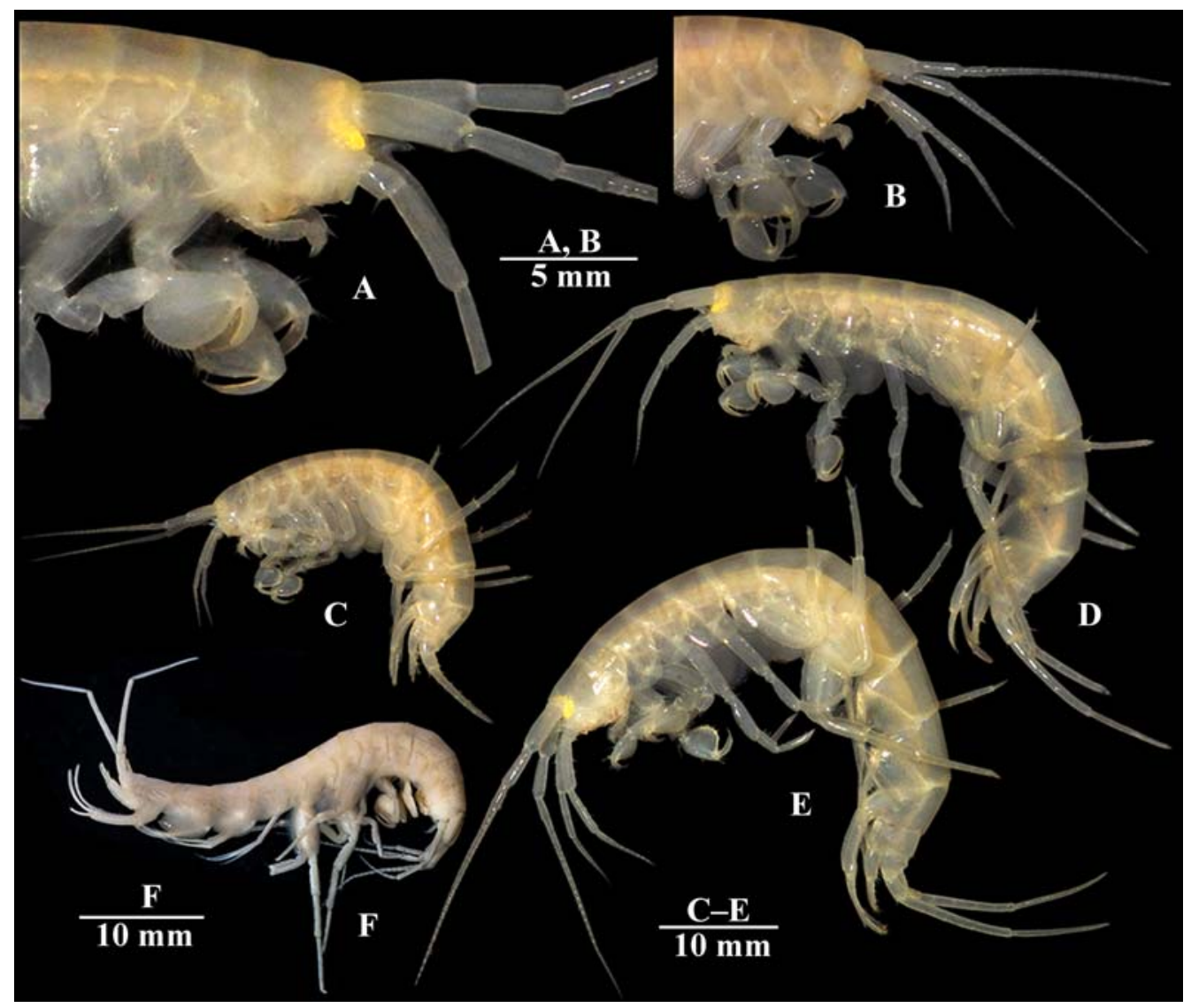

Fig. 23. Live coloration (A-E) and fixed individual (F) of Niphargus cf. magnus Birštein, 1940 from Agura River, Krasnodar Krai, Khosta City District, south-western Caucasus.

Рис. 23. Прижизненная окраска (А-Е) и зафиксированная особь (F) Niphargus cf. magnus Birštein, 1940 из реки Агура, Краснодарский край, Хостинский район, юго-западный Кавказ.

III and mouthparts. At the same time, by our opinion the specimens identified by Sidorov (2014) as N. iniochus from the Nizhne-Shakuranskaya (=Lower Shakuran) Cave (unfortunately, genetically unexamined) is actually a mediumsized species from the "Niphargus magnus" species complex, not related to $N$. iniochus (see Fig. 24). Thus, we question this conclusion.

ECOLOGY. Niphargus magnus was originally described as subterranean species from a subterranean stream and shallow puddles in Otapa Cave (Birštein, 1940). At the same time, based on our observations, the species usually lives in shallow water ponds outside caves, similar to other epigean species described above.
Unlike other species, it prefers small standing reservoirs in the mountain-forest zone (Fig. 22B, C), often completely filled with fallen leaves (Fig. 22D). It is possible that some populations or cryptic species have adapted to living in subterranean stagnant reservoirs or enter caves together with flood water. In the field, we noted that individuals of this species curl up in a spherical structure as a reaction to the external action (e.g., attack of the predator), which is observed for the first time (Fig. 22A).

DISTRIBUTION. The species described by Birštein (1940) is probably endemic to Eastern Abkhazia, since it was originally described from the Otapa Cave located in the Ochamchir Dis- 


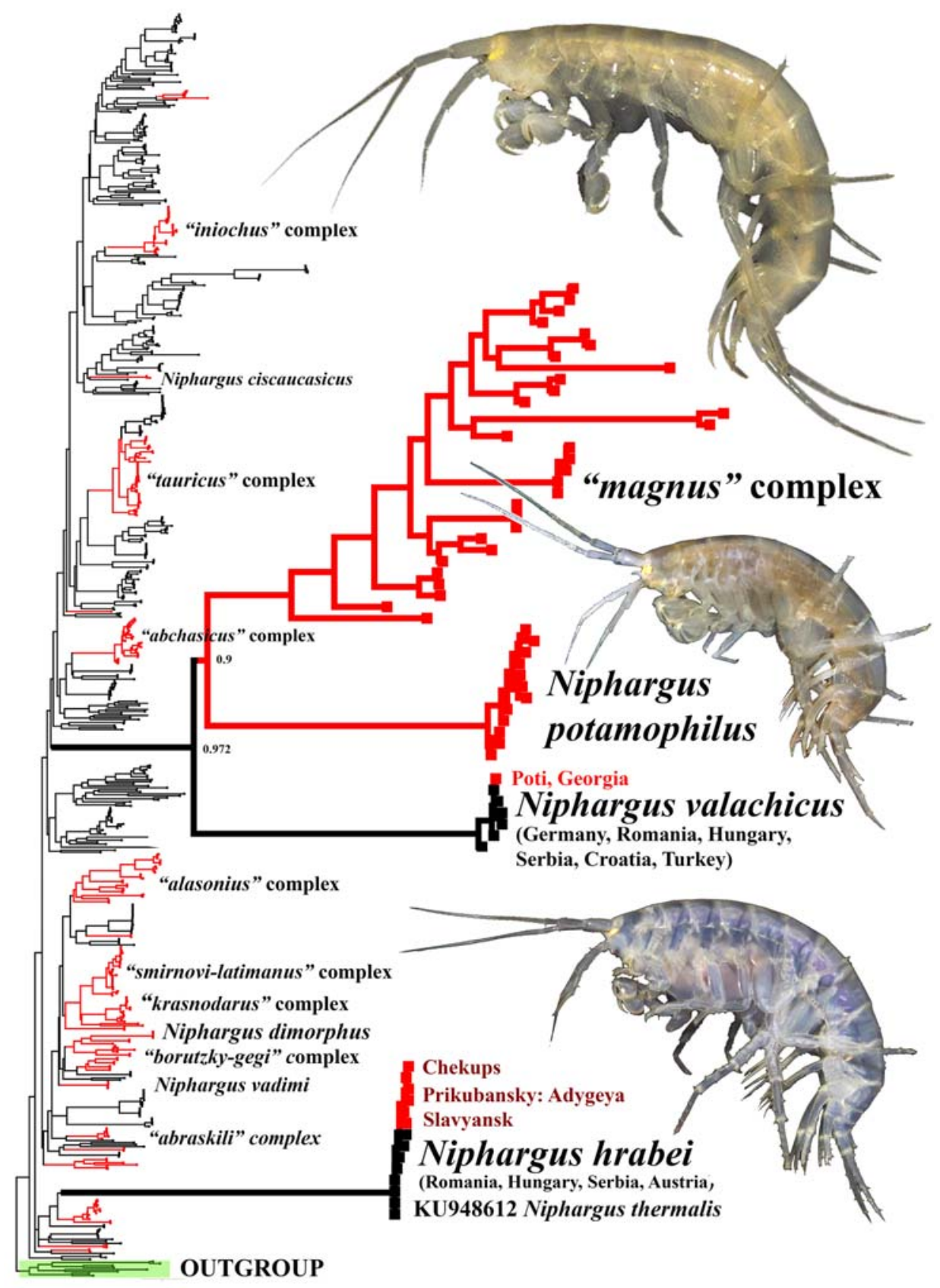

Fig. 24. Reconstruction of phylogenetic positions of the studied species of the genus Niphargus based on COI mtDNA gene marker (ML algorithm, GTR+G+I model, Akaike Information Criterion (AIC) — aLRT SH-like fast likelihood-based method). The sequences of the related species were taken from the GenBank (NCBI) database. Caucasian (+Crimean) clades are marked with red.

Рис. 24. Филогенетическая реконструкция исследуемых видов рода Niphargus на основе генетического маркера COI мтДНК (алгоритм ML, модель GTR+G+I, информационный критерий Akaike (AIC) - aLRT SH-подобный метод быстрого правдоподобия). Сиквенсы родственных видов были взяты из базы данных GenBank (NCBI). Кавказские (+крымские) клады отмечены красным. 
trict of Abkhazia (Birštein, 1940, 1952). At the same time, molecular genetic studies revealed that the Colchis lowland is inhabited by a complex of several cryptic species (see Fig. 24) distributed from Tuapse (Russian Federation) to Hopa (north-eastern Turkey) (Fig. 1), the study of which requires a detailed study and clarification of the ranges of each of the species.

\section{Phylogenetic part}

The calculated intraspecific pairwise genetic distances ( $p$-distances) in the studied populations of $N$. potamophilus, N. hrabei and $N$. valachicus are very low, being about 0.012 , 0.002 and 0.001 substitutions per 100 nucleotides $(1.2,0.2$ and $0.1 \%)$, respectively. The average genetic differences of Caucasian populations of $N$. hrabei and $N$. valachicus from others localities (Germany, Austria, Serbia, Croatia, Hungary, Romania and Turkey), based on the sequences from GenBank (NCBI), are about 0.006 and 0.005 substitutions per 100 nucleotides ( 0.6 and $0.5 \%$ ), respectively. At the same time, the estimated intraspecific pairwise genetic distance ( $p$-distances) in the studied population of $N$. magnus is 0.131 substitutions per 100 nucleotides $(13.1 \%)$, which indicates the presence of a complex of several cryptic species (see Fig. 24).

The interspecific pairwise genetic distances ( $p$-distances) between the phylogenetically related $N$. valachicus, $N$. potamophilus and $N$. magnus (complex) were calculated (Table 1) based on obtained (COI mtDNA) and sequences from GenBank (NCBI). The genetic distanc- es exceed $0.175-0.211$ substitutions per 100 nucleotides (17-21\%). The estimated divergence time (node ages) (after Guy-Haim et al. (2018) suggested minimum 0.0077 substitution/Mya for molecular clock calibration based on COI mtDNA gene marker for Typhlocaris spp. and maximum 0.0516 substitution/Mya for molecular clock calibration based on COI mtDNA gene marker for Stygiocaris spp.) vary from 3.4 to 27 Mya, respectively, which suggests a long-time separation/isolation of these lineages. However, for more accurate dating, special studies are needed.

Our phylogenetic reconstruction, based on sequences of COI mtDNA gene marker of the studied species, confirmed the well-isolated position of $N$. hrabei, which is not related to any other Caucasian species of the genus Niphargus, as well as the close phylogenetic relationship between $N$. valachicus, $N$. potamophilus and N. magnus (see Fig. 24). The presented phylogenetic tree (Fig. 24) also demonstrates a great abundance of the Caucasian lineages within the genus Niphargus, and the presence of several well-isolated lineages within the "Niphargus magnus" species complex.

\section{Discussion}

As noted earlier, molecular genetic studies of numerous European and Balkanian niphargids have postulated that species of the genus tend to have a limited distribution, being mostly narrow endemics (Fišer et al., 2008; Eme et al., 2017; Delić et al., 2017). At the same time, widespread taxa that have been subjected to

Table 1. Pairwise genetic (COI mtDNA) distances ( $p$-distances) and estimated node age (Mya) (after Guy-Haim et al. (2018)) of studied species of the genus Niphargus (our data and data from GenBank

(NCBI) database).

Таблица 1. Попарные генетические (COI мтДНК) расстояния ( узлов (млн. лет) (по Guy-Haim et al. (2018)) изученных видов рода Niphargus (наши данные и данные базы GenBank (NCBI)).

\begin{tabular}{|l|cc|}
\hline \multicolumn{1}{|c|}{ Taxon } & \multicolumn{2}{|c|}{ Calculated p-distances / Estimated node age (Mya) } \\
\hline & Niphargus valachicus & Niphargus potamophilus \\
\hline Niphargus potamophilus & $0.175 / 3.39-22.72$ & \\
Niphargus magnus & $0.211 / 4.09-27.40$ & 0.209 / 4.05-27.14 \\
\hline
\end{tabular}


careful molecular genetic studies, as a rule, turned out to be complexes of cryptic species, which is also true even for epigean species (Lefébure et al., 2006, 2007; Delić et al., 2017). Ranges of the species distribution over $200 \mathrm{~km}$ are considered the exception rather than the rule in niphargids (Trontelj et al., 2009).

According to our molecular genetic data, different distribution patterns were observed in the studied species. The previously relatively widespread Caucasian N. magnus is indeed represented by numerous narrowly localized species, widely distributed in the Colchis, while the other three species show low intraspecific genetic divergence over the area of distribution. Moreover, the Caucasian specimens of N. hrabei and $N$. valachicus are almost identical to the European and Turkish ones, and N. potamophilus also showed weak genetic divergence between most distant studied localities separated for more than $250 \mathrm{~km}$ (Figs 1; 23). It is also extremely interesting and promising to study the close phylogenetic relationships of two widely distributed species (N. valachicus and N. potamophilus) with the "Niphargus magnus" species complex, whose species are also epigean, but characterized by a narrowly localized distribution. Perhaps this will help to understand the mechanisms of settlement. Actually, the difference between the habitats of $N$. magnus and other studied epigean species is that it is more often found in fairly well-isolated forest reservoirs located in various ravines, between which the flood exchange is difficult, than in coastal plains.

The question of how these species are dispersed remains open. It is considered that the dispersal of such species is mediated by floods or seasonal river flooding (passive long-range dispersal events) (Van Leeuwen et al., 2013; Copilaş-Ciocianu et al., 2018), which, however, cannot explain the isolation of $N$. potamophilus and $N$. hrabei in the lower and middle reaches of the Kuban River, respectively (Fig. 1). Also, the very low genetic divergence of European/Turkish/Caucasian/Iranian populations of N. valachicus and European/Caucasian populations of $N$. hrabei, separated by the Black
Sea from the studied populations from the Russian territory, suggests a recent dispersal scenario instead of either direct gene transfer or water flows. According to the proposed hypotheses, it can be assumed that the observed pattern of settlement was formed recently, possibly in the Late Pleistocene (129-11.7Kya), when the water level and salinity of the Black and Caspian seas varied significantly, and there were even several episodes of their direct interconnection (Badertscher et al., 2011), or these species invaded coastal freshwaters from the Paratethys during the Pliocene (5.3-2.58Mya) (Straškraba, 1972; Sket, 1981). According to our data, the first dating looks more real.

Also, the well-isolated phylogenetic position of N. potamophilus with a relatively shallow intraspecific genetic structure and relatively long isolation (at least 3.5Mya) from related species (Fig. 1; Table 1) coincides with earlier molecular genetic data obtained on other invertebrates, which indicate the existence of an ancient Plio-Pleistocene refugium in the deltas of the rivers of the Sea of Azov, where genetically stable populations/species were preserved for a long time (Tomilova et al., 2020). The separation of different phylogenetic lineages in the rivers of the Sea of Azov basin probably occurred in the Late Pliocene (about 3.6$2.6 \mathrm{Mya}$ ), which probably contributed to the change in the boundaries of freshwater basins in the Ponto-Caspian region (Tomilova et al., 2020).

According to our observations, all the studied species (except $N$. magnus) live in exactly the same habitats (biotopes), but the epigean niphargids in the Caucasus have never been found together, in the same water reservoir, or even in neighboring ones, but were always separated by quite significant distances, in contrast to the data from the Danube delta (CopilaşCiocianu et al., 2018). In the Caucasus, these species usually occur together with epigean representatives of the family Crangonyctidae (e.g., Synurella spp. or Lyurella spp.), but never with other niphargids. Due to the relatively large distances between the localities we have studied, it is impossible to represent precise 
conclusions about the direct ecological competition of these species, but we will try to do this by analyzing stable isotopes $\left(\delta^{13} \mathrm{C} / \delta^{15} \mathrm{~N}\right)$ in the future (see Marin et al., 2021). It is possible, that the niche differentiation between niphargids is really weaker than in Niphargidae/Crangonyctidae sympatric species (Akbulut et al., 2001; Copilaş-Ciocianu et al., 2014, 2018).

\section{Acknowledgements}

The study is supported by the Russian Foundation for Basic Research (RFBR) (grant 2004-00803_A). Authors are sending their special thanks to Dr. Roman Dbar (Institute of Ecology of the Academy of Sciences of Abkhazia) for the help during the sampling in Abkhazia and Roman A. Rakitov (Paleontological Institute of Russian Academy of Sciences) for his help with SEM photos, and Dr. Vycheslav S. Labay (TINRO), who greatly reviewed and improved the manuscript.

\section{References}

Akbulut M., Sezgin M., Culha M., Bat L. 2001. On the occurrence of Niphargus valachicus Dobreanu and Manolache, 1933 (Amphipoda, Gammaridae) in the western Black sea region of Turkey // Turkish Journal of Zoology. Vol.25. P.235-239.

Birštein J.A. 1940. [To the fauna of cave-dwelling amphipods of Abkhazia] // Byulleten Moskovskogo obshchestva ispytatieley prirody. Otdel Biologicheskii. Vol.49. No.3-4. P.47-55 [in Russian with German abstract].

Birštein J.A. 1952. [Subterranean amphipods of the Khosta-Gudauta region (western Transcaucasia)] // Byulleten Moskovskogo obshchestva ispytatieley prirody. Otdel Biologicheskii. Vol.57. No.1. P.26-39 [in Russian].

Birštein J.A. 1954. [Records of the Subterranean Amphipod Niphargus (Crustacea, Amphipoda) in the Lower Don Region and the Kuban Basin] // Zoologicheskii Zhurnal. Vol.33. No.5. P.1025-1031 [in Russian].

Cărăuşu S., Dobreanu E., Manolache C. 1955. Amphipoda //Fauna Republicii Populare Romine. Crustacea. Vol.4. P.92-96.

Copilaş-Ciocianu D., Grabowski M., Pârvulescu L., Petrusek A. 2014. Zoogeography of epigean freshwater Amphipoda (Crustacea) in Romania: fragmented distributions and wide altitudinal variability // Zootaxa. Vol.3893. P.243-260. http://doi.org/10.11646/ zootaxa.3893.2.5

Copilaş-Ciocianu D., Fišer C., Borza P., Balázs G., Angyal D., Petrusek A. 2017. Low intraspecific genetic diver- gence and weak niche differentiation despite wide ranges and extensive sympatry in two epigean Niphargus species (Crustacea: Amphipoda) // Zoological Journal of the Linnean Society. Vol.181. P.485-499. http://doi.org/10.1093/zoolinnean/zlw031

Copilaş-Ciocianu D., Fišer C., Borza P., Petrusek A. 2018. Is subterranean lifestyle reversible? Independent and recent large-scale dispersal into surface waters by two species of the groundwater amphipod genus Niphargus // Molecular Phylogenetics and Evolution. Vol.119. P.37-49. https://doi.org/10.1016/j.ympev.2017.10.023

Dedju I.I. 1980. [Amphipoda of Fresh and Brackish Waters in the Southwest of the USSR]. Kishinev: Shtiinca. 223 p. [In Russian]

Delić T., Trontelji P., Rendos M., Fišer C. 2017. The importance of naming cryptic species and the conservation of endemic subterranean amphipods // Scientific Reports. Vol.7. No.1. P.3391. http://doi.org/ 10.1038/s41598-017-02938-Z

Eme D., Zagmajster M., Delić T., Fišer C., Flot J.-F., Konecny-Dupré L., Pálsson S., Stoch F., Zakšek V., Douady C.J., Malard F. 2017. Do cryptic species matter in macroecology? Sequencing European groundwater crustaceans yields smaller ranges but does not challenge biodiversity determinants // Ecography. Vo.41. P.424-436. https://doi.org/10.1111/ ecog.02683

Esmaeili-Rineh S., Sari A. 2013. Two new species of Niphargus Schiödte, 1849 (Crustacea: Amphipoda: Niphargidae) from two caves in Iran // Journal of Natural History. Vol.47. P.2649-2669. https://doi.org/ 10.1080/00222933.2013.802041

Esmaeili-Rineh S., Sari A., Delić T., Moškrič A., Fišer C. 2015. Molecular phylogeny of the subterranean genus Niphargus (Crustacea: Amphipoda) in the Middle East: a comparison with European Niphargids // Zoological Journal of the Linnean Society. Vol.175. P.812826. http://doi.org/10.1111/zoj.12296

Fišer C. 2012. Niphargus: a model system for evolution and ecology // Culver D.C., White W.B. (eds.). Encyclopedia of caves. New York: Academic Press. P.555564. https://doi.org/10.1016/B978-0-12-3838322.00082-7

Fišer C., Sket B., Stoch F. 2006. Distribution of four narrowly endemic Niphargus species (Crustacea: Amphipoda) in the western Dinaric region with description of a new species // Zoologischer Anzeiger. Vol.245. P.77-94. https://doi.org/10.1016/j.jcz.2006. 05.003

Fišer C., Çamur-Elipek B., Özbek M. 2009. The subterranean genus Niphargus (Crustacea, Amphipoda) in the Middle East: a faunistic overview with descriptions of two new species // Zoologischer Anzeiger. Vol.248. P.137-150. https://doi.org/10.1016/j.jcz.2009.03.003

Fišer C., Pipan T., Culver D.C. 2014. The vertical extent of groundwater metazoans: an ecological and evolutionary perspective // Bioscience. Vol.64. P.971-979. https://doi.org/10.1093/biosci/biu148

Fišer C., Sket B., Trontelj P. 2008. A phylogenetic perspective on 160 years of troubled taxonomy of Niphar- 
gus (Crustacea: Amphipoda) // Zoologica Scripta. Vol.37. P.665-680. https://doi.org/10.1111/j.14636409.2008.00347.x

Folmer O., Black M., Hoeh W., Lutz R., Vrijenhoek R. 1994. DNA primers for amplification of mitochondrial cytochrome c oxidase subunit I from diverse metazoan invertebrates // Molecular Marine Biology and Biotechnology. Vol.3. P.294-299.

Guy-Haim T., Simon-Blecher N., Frumkin A., Naaman I., Achituv Y. 2018. Multiple transgressions and slow evolution shape the phylogeographic pattern of the blind cave-dwelling shrimp Typhlocaris // PeerJ. Vol.6. e5268. https://doi.org/10.7717/peerj.5268

Guindon S., Dufayard J.F., Lefort V., Anisimova M., Hordijk W., Gascuel O. 2010. New Algorithms and Methods to Estimate Maximum-Likelihood Phylogenies: Assessing the Performance of PhyML 3.0 // Systematic Biology. Vol.59. No.3. P.307-321. https:/ /doi.org/10.1093/sysbio/syq010

Hebert P.D.N., Ratnasingham S., de Waard J. 2003a. Barcoding animal life: cytochrome c oxidase subunit 1 divergences among closely related species // Proceedings of the Royal Society of London B (Supplement). Vol.270. P.S96-S99. https://doi.org/10.1098/ rsbl.2003.0025

Hebert P.D.N., Cywinska A., Ball S.L., de Waard J.R. 2003b. Biological identifications through DNA barcodes // Proceedings of the Royal Society of London. Series B. Vol.270. P.313-321.https://doi.org/10.1098/ rspb.2002.2218

Horton T., Lowry J., De Broyer C., Bellan-Santini D., Coleman C.O., Daneliya M., Dauvin J-C., Fišer C., Gasca R., Grabowski M., Guerra-García J.M., Hendrycks E., Holsinger J., Hughes L., Jaume D., Jazdzewski K., Just J., Kamaltynov R.M., Kim Y.-H., King R., Krapp-Schickel T., LeCroy S., Lörz A.-N., Senna A.R., Serejo C., Sket B., Tandberg A.H., Thomas J., Thurston M., Vader W., Väinölä R., Vonk R., White K., Zeidler W. 2017. World Amphipoda Database. Accessed at www.marinespecies.org/amphipoda./ aphia.php? $\mathrm{p}=$ taxdetailsandid $=545672$ on 2017-06-08.

Karaman G.S. 1998. First discovery of the family Niphargidae (Gammaridea) in Iran // The Montenegrin Academy of Sciences and Arts: Glasnik of the Section of Natural Sciences. Vol.12. P.9-22.

Karaman G.S. 2012. Contribution to knowledge of Amphipoda. 256. New species of the subterranean genus Niphargus Schiödte, 1849 (Amphipoda, Gammaridea, Niphargidae) from Russia, N. krasnodarus sp. n. // Biologia Serbica. Vol.34. No.1. P.12-16.

Kozlov A.M., Darriba D., Flouri T., Morel B., Stamatakis A. 2019. RAxML-NG: A fast, scalable, and userfriendly tool for maximum likelihood phylogenetic inference // Bioinformatics. btz305. https://doi.org/ 10.1093/bioinformatics/btz305

Krever V., Zazanashvili N., Jungius H., Williams L., Petelin D. 2001. Biodiversity of the Caucasus ecoregion. Moscow: World Wide Fund for Nature. 180 pp.

Lefébure T., Douady C.J., Gouy M., Trontelj P., Briolay J., Gibert J. 2006. Phylogeography of a subterranean amphipod reveals cryptic diversity and dynamic evolu- tion in extreme environments // Molecular Ecology. Vol.15. P.1797-1806. http://doi.org/10. 1111/j.1365294X.2006.02888.x

Lefébure T., Douady C.J., Malard F., Gibert J. 2007. Testing dispersal and cryptic diversity in a widely distributed groundwater amphipod (Niphargus rhenorhodanensis) // Molecular Phylogenetics and Evolution. Vol.42. P.676-686. http://doi.org/10.1016/ j.ympev. 2006.08.020

van Leeuwen C.H.A., Huig N., van der Velde G., van Alen T.A., Wagemaker C.A.M., Sherman C.D.H., Klaassen M., Figuerola J. 2013. How did this snail get here? Several dispersal vectors inferred for an aquatic invasive species // Freshwater Biology. Vol.58. P.88-99. http://doi.org/10.1111/fwb.12041

Marin I.N. 2019. Crustacean "cave fishes" from the Arabika karst massif (Abkhazia, Western Caucasus): new species of stygobiotic crustacean genera Xiphocaridinella and Niphargus from the Gegskaya Cave and adjacent area // Arthropoda Selecta. Vol.28. No.2: 225-245. https://doi.org/10.15298/arthsel. 28.2.05

Marin I.N. 2020. The Quaternary speciation in the Caucasus: a new cryptic species of stygobiotic amphipod of the genus Niphargus (Crustacea: Amphipoda: Niphargidae) from the Kumistavi (Prometheus) Cave, Western Georgia // Arthropoda Selecta. Vol.29. No.4. P.419-432. https://doi.org/10.15298/arthsel.29.4.04

Marin I., Palatov D. 2019a. A new species of the genus Niphargus (Crustacea: Amphipoda: Niphargidae) from the south-western part of the North Caucasus // Zoology in the Middle East. Vol.65. Is.4. P.336-346. https://doi.org/10.1080/09397140.2019.1663907

Marin I., Palatov D. 2019b. An occasional record of the amplexus in epigean Niphargus (Amphipoda: Niphargidae) from the Russian Western Caucasus // Zootaxa. Vol.4701. No.1. P. 97-100. http://doi.org/10.11646/ zootaxa.4701.1.8

Marin I., Palatov D. 2021. Cryptic refugee on the northern slope of the Greater Caucasian Ridge: Discovery of Niphargus (Crustacea: Amphipoda: Niphargidae) in the North Ossetia-Alania, North Caucasus, separated from its relatives in the late Miocene // Zoologischer Anzeiger. Vol.292.P.163-183.http://doi.org/10.1016/ j.jcz.2021.03.002

Marin I., Krylenko S., Palatov D. 2021. The Caucasian relicts: a new species of the genus Niphargus (Crustacea: Amphipoda: Niphargidae) from the GelendzhikTuapse area of the Russian southwestern Caucasus // Zootaxa. Vol.4963. No.3. P.483-504. https://doi.org/ 10.11646/zootaxa.4963.3.5

McInerney C.I., Maurice L., Robertson A.L., Knight L.R.F.D., Arnscheidt J., Venditti C., Dooley J.S.G., Mathers T., Matthijs S., Eriksson K., Proudlove G.S., Hänfling B. 2014. The Ancient Britons: groundwater fauna survived extreme climate changes over tens of millions of years across NW Europe // Molecular Ecology. Vol.23. P.1153-1166. http://doi.org/ $10.1111 /$ mec. 12664

Myers N., Mittermeier R.A., Mittermeier C.G., da Fonseca G.A.B., Kent J. 2000. Biodiversity hotspots for con- 
servation priorities // Nature. Vol.403. P.853-858. https://doi.org/10.1038/35002501

Sidorov D.A. 2014. Towards the systematics of the subterranean amphipod genus Niphargus (Crustacea: Amphipoda: Niphargidae) of Transcaucasia: new records of $N$. inermis and $N$. iniochus in Abkhazia // Arthropoda Selecta. Vol.23. No.4. P.363-377.

Sket B. 1981. [Distribution, Ecological, Character and Phylogenetic importance of Niphargus valachicus (Amphipoda, Gammaridae, S.L.)] // Biology Vestnik. Vol.29. No.1. P.87-103 [in Slovenian with English summary].

Straškraba M. 1959. [Contribution to the knowledge of amphipoda in Slovakia] // Biologia. Vol.3. P.161172. [in Czeck with German summary].

Takhteev V.V., Berezina N.A., Sidorov D.A. 2015. Checklist of the Amphipoda (Crustacea) from continental waters of Russia, with data on alien species // Arthropoda Selecta. Vol.24. No.3.P.335-370.https://doi.org/ 10.15298/arthsel.24.3.09

Tomilova A.A., Lyubas A.A., Kondakov A.V., Vikhrev I.V., Gofarov M.Y., Kolosova Y.S., Vinarski M.V., Palatov D.M., Bolotov I.N. 2020. Evidence for Plio-
Pleistocene Duck Mussel Refugia in the Azov Sea River Basins // Diversity. Vol.12. P.118. https:// doi.org/10.3390/d12030118

Trontelj P., Douady C., Fišer C., Gibert J., Gorički Š., Lefébure T., Sket B., Zakšek V. 2009. A molecular test for hidden biodiversity in groundwater: how large are the ranges of macro-stygobionts? // Freshwater Biology. Vol.54. P.727-744. https://doi.org/10.1111/ j.1365-2427.2007.01877.x

Turbanov I.S., Palatov D.M., Golovatch S.I. 2016. [The state of the art of biospeleology in Russia and other countries of the former Soviet Union: A review of the cave (endogean) invertebrate fauna. I. Introduction Crustacea] // Zoologicheskii zhurnal. Vol.95. No.10. P.1136-1159 [in Russian; English translation: Entomological Review. 2016, Vol.96. No.7. P.926-963]. https://doi.org/10.1134/S0013873816070162

Väinölä R., Witt J.D.S., Grabowski M., Bradbury J.H., Jazdzewski K., Sket, B. 2008. Global diversity of amphipods (Amphipoda; Crustacea) in freshwater // Hydrobiologia. Vol.595. P.241-255. https://doi.org/ 10.1007/s10750-007-9020-6

Responsible editor K.G. Mikhailov 